\title{
Corporate Financial Policies and Performance Prior to Currency Crises
}

By: Arturo Bris, Yrjö Koskinen, and Vicente Pons

William Davidson Working Paper Number 386 


\title{
Corporate Financial Policies and Performance Prior to Currency Crises $^{x}$
}

\author{
Arturo Bris \\ Yrjö K oskinen \\ Yale School of Management Stockholm School of Economics \\ Vicente Pons \\ Yale School of M anagement
}

J une 25, 2001

${ }^{x}$ We thank Mariassunta Giannetti, Loriana Pelizzon and audiences at Yale School of Management, Stockholm School of Economics, Norges Bank, Boston College, University of California-Irvine, University of A msterdam and 2001 FMA European Meeting in Paris for helpful comments. Bris is from Yale School of Management, 135 Prospect Street, New Haven, CT 06511-3729, USA. Tel: +1-203-432-5079, fax: +1-203-432-6970, e-mail: arturo.bris@yale.edu. Koskinen is from Stockholm School of Economics, P.O.Box 6501, SE-113 83 Stockholm, Sweden. Tel: +46-8-736-9145, fax: +46-8-312-327, e-mail: yrjo.koskinen@hhs.se. Pons is from Yale School of Management, 135 Prospect Street, New Haven, CT 06511-3729, USA. Tel: +1-203-432-5661, fax: +1-203-432-6974, e-mail: vicente.pons@yale.edu. Koskinen is grateful to Bankforskningsinstitutet for ..nancial support. The authors are responsible for all remaining errors. 


\begin{abstract}
A bstract
Using company level data from 17 countries that have suxered a currency crisis during the past decade, this paper documents that ..rms have increasing leverage and declining pro..tability prior to a crisis. After sorting companies into two groups based on their exchange rate beta, we show that companies that bene.tt from currency depreciations have higher leverage, lower earnings to revenue ratios and lower interest coverage ratios compared to ..rms that are harmed by currency deprecations. These results are consistent with the recent literature that puts the ..nancial policies and performance of corporations as the central issue in currency crises.
\end{abstract}

KEYWORDS: currency crises, corporate leverage, capital structure, pro..tability, exchange rates. J EL classi..cation: F 3, F 4, G3 
A re currency crises caused by irresponsible macroeconomic policies? The answer used to be an unquali..ed yes: a currency crisis was a just retribution for government mismanagement. However, the recent crisis in A sia has led many observers to question this view. Most of the a- icted economies had budget surpluses and healthy foreign exchange reserves. While current account de.cits were large in some countries ( $T$ hailand and Malaysia), they were very modest in others (South K orea and Indonesia). Thus it is dic cult to argue that currency depreciations were needed because of macroeconomic reasons.

This paper contributes to the growing literature that places the corporate sector and its policies as the central issue in currency crises. In order to examine the role of corporations and their policies in currency crises, this paper considers micro level data of those countries that have suxer ed a currency crisis in the last ten years. We compile a database that contains data on ..rms in seventeen countries. We analyze the ..rms' ..nancial policies and pro..tability ratios First we sort companies into two groups using individual companies' stock market returns. In the ..rst group we have companies whose stock returns decrease when the domestic currency appreciates with respect to the U.S. dollar (negative exposure companies) and in the second group those companies whose stock returns increase (positive exposure companies). After sorting the companies into these two groups, we show that those companies with negative exposure have higher leverage than those companies that have positive exposure, even tough all companies increase their leverage prior to a currency depreciation. In addition, we analyze companies pro..tability and liquidity using several standard ratios, and show that pro..tability decreases for all companies before a currency crisis, but the exect is more pronounced for the negative exposure companies. We also show, in a multivariate regression framework controlling for ..rm characteristics, that companies that bene.t. from a currency depreciation have higher leverage than companies that are harmed by the depreciation.

We also examine how ..rms' leverage arects the amount of currency depreciations. We ..nd that it is especially the leverage of negative exposure companies that axects the magnitude of currency depreciations. Finally, we argue that countries with the weakest corporate governance mechanisms are more prone for this phenomenon of excessive leverage leading to a currency depreciation because of forced reliance on debt in ..nancing investments. We operationalize this by using the variables developed by La Porta et. al. in addition to leverage ratios to explain the magnitude of currency depreciations.

The results of this paper provide support for the implications derived in B ris and Koskinen (2001), who argue that excessive leverage and risky investments among exporting companies lead to currency depreciations. A ghion et al. (2000) and K rugman (1999) also argue that ..rms' ..nancial distress is the important factor causing currency crises. Shocks (or loss of con..dence) cause depreciations which then cause ..nancial distress problems for corporations and further depreciations. The hypothesis underlying 
such argument is that currency depreciations decrease ..rms' pro.tability. In order for these models to hold empirically, one would expect the increase in leverage and decline in pro..tability be more pronounced among positive exposure ..rms. O ur data doesn't support that.

In addition to these ..nancial distress models, J ohnson et al. (2000) emphasize problems in corporate governance as an explanation to the A sian crisis and show that lack of outside investor protection is related to the amount of depreciation in emerging markets. We obtain results, consistent with J ohnson et al. (2000), and we are able to provide an alternative explanation for these ..ndings: poor corporate governance mechanisms lead to forced debt ..nancing and thus, through high leverage, ultimately to currency depreciations ${ }^{1}$.

There are several other papers that depart from the traditional macroeconomic reasoning in explaining currency crises. Corsetti, Pesenti and Roubini (1998a, 1998b, 1999) argue that creditors' capital was at least implicitly guaranteed in some Asian countries, if ..nancial dic culties were to arise. This would naturally lead to overinvestment in risky projects at the expense of safer ones. Chang and Velasco (1998a, 1998b) model a currency crisis in a same way as Diamond and Dybvig (1983) model a bank run. W ith foreign borrowing and a ..xed exchange rate, a run on banks becomes a run on the currency. In Caballero and K rishnamurthy (1999) outłow of capital can lead to domestic ..re sales, because a country has a lack of international collateral, thus deepening a capital account crisis to a full ..nancial crisis. A llen and Gale (2000) argue that currency crises can serve as a risk sharing mechanism between domestic bank depositors and international bond markets

The next section of the paper describes the data and its sources. In Section II we analyze the stock price reaction of the companies in our sample to a currency depreciation, based on our measures of exchange rate exposure. In Section III we study the relationship between leverage and exchange rates. In Section IV we relate exchange rate exposure to several dixerent measures of pro..tability. In Section $\mathrm{V}$ we provide cross-sectional evidence on the determinants of a company's capital structure and on the amount of a currency depreciation. Section VI concludes the paper.

\section{Data}

\section{A Sample description}

\footnotetext{
${ }^{1} M$ itton (2001) provides company level evidence, that corporate governance variables al so help to explain how individual companies performed in the A sian crisis.
} 
Throughout the paper, a crisis is de..ned as the event in which a government decides to let its previously ..xed currency $\ddagger$ oat or administratively devalues it. We only consider currencies that can $¥$ oat within a band or that are..xed. Bands can be either nominal or real, so crawling peg currencies are also considered ..xed for our purposes.

We obtain information about currency crises that have occurred in the period 1985-2000. These are partly compiled in Kaminsky and Reinhart (1996). Additionally, Italy, the United K ingdom and the countries that experienced the A sian crises of 1997 are also included in the sample. When a country has suxered several crises in the period 1985-2000 (this is the case, for instance, for Brazil, Chile, Spain, and Turkey), exclusively the last one is considered. The ..nal sample of crises includes seventeen countries, and its description is in Table I. There have been other major currency depreciations not included in the ..nal sample for a variety of reasons. For example, we do not include the R ussian crisis in 1998 because of a lack of data on R ussian ..rms. We also eliminate Bolivia, Chile, Colombia, Israel, Peru, and U ruguay, because we lack stock price data before the crises. For some countries the most recent crisis has not been considered due to the unavailability of data after the crisis ${ }^{2}$. B razil, for instance, suxered its last crisis in 1999. Finally, some A sian countries, like J apan, that experienced considerable depreciations did not have a system of ..xed rates prior to the crises.

For each country in the sample, Datastream provides a Global M arket Index, that includes a varying number of ..rms per country ${ }^{3}$. Datastream also provides accounting information regarding all the available ..rms in the corresponding market, for a window of ...ve years around the year of the currency crisis.

We are able to ..nd information in Datastream for 3,617 ..rms from the seventeen countries we consider. A mong those, 2,081 ..rms are from A sia ${ }^{4}$, 1,403 from E uropean countries, and 133 ..rms from Latin America. We compare the number of ..rms in our sample with the total number of ..rms in the corresponding exchange as of December of the corresponding crisis year, from the International Federation of Stock Exchanges. On average, our sample contains 54.75 percent of all the ..rms listed in a country's main stock exchange. This percentage is lower for Latin A merican countries, where currency depreciations happened earlier and

\footnotetext{
${ }^{2}$ We require six years of past information, and two years of post-crisis data, on stock prices for the ..rms available in the sample in order to perform the estimation.
}

${ }^{3}$ There are 50 stocks from Brazil, 50 from Venezuela, 90 from M exico, 50 from Finland, 50 from Norway, 120 from Spain, 70 from Sweden, 50 from Turkey, 550 from the UK, 160 from Italy, 50 from Indonesia, 100 from South K orea, 90 from M alaysia, 50 from the Phillippines, 100 from Singapore, 70 from Taiwan, 50 from Thailand, included in each market index.

${ }^{4}$ Pomerleano, with a sample of ..rms that include J apan and Hong K ong, employs data from 734 companies. 
hence the lack of data problem is more severe.

\section{[Insert Table IA ]}

In Table IA we have calculated the domestic stock market return at the time of the currency dep reciation, as well as in the ...ve months that surround the crisis. On average stock prices decline by $1.83 \%$ in the month following the depreciation month. We also calculate the currency depreciation relative to the US dollar ${ }^{5}$. At the same time, the average currency depreciation in our sample amounts to 27.01 percent in the 5 months that surround the crises. The largest depreciation happened in B razil (94.7 percent), the lowest in Venezuela ( 3.56 percent appreciation in ..ve months). The average debt-to-value ratio (book values) for the total sample is 51.2 percent, with South Korea having the highest ratio (75.18 percent), and Brazil the lowest (25.15 percent). By regions, A sian countries display the highest debt levels, with an average of 57.68 percent. European countries had a 45.81 percent debt ratio and the average for Latin A merica is 31.52 percent.

Table IB describes the exchange rate regimes for the countries in our sample. Strictly speaking, only B razil, Mexico, and the Philippines had ..xed exchange rates prior to their currency devaluations. In addition to the countries in the ERM, Finland, Norway and Sweden maintained the exchange rate within a band with respect to the ECU. Other countries (South Korea, Indonesia, Singapore, and Taiwan) ..xed their real exchange rates with respect to either the dollar or a basket of currencies. M alaysia and Venezuela allowed for łuctuations with respect to the dollar. Figure 1 shows that, although pegged to the dollar, Lat in A merican currencies were the ones that $\ddagger$ uctuated the most before the crises. B razil pegged the real only six months before its last devaluation, and M exico suxered several crises before the ones we consider in this paper. A sian exchange rates are not excessively volatile in the last six years before the crises (the standard deviation of the monthly change in exchange rates is 0.84 percent in A sia, 1.54 percent in Europe, and 5.52 in Latin A merica).

\section{[Insert Tabl e IB] \\ [Insert Figure 1]}

In the next section we survey the literature on exchange rate exposure and propose a new methodology that allows us to dixerentiate ..rms depending on whether they bene.t from or are harmed by currency depreciations. We regress the stock return of every ..rm on exchange rate changes and the component of the domestic market return that is orthogonal to the changes in the exchange rate.

\footnotetext{
${ }^{5} \mathrm{~T}$ hroughout the paper, exchange rates are calculated as units of dollars per domestic currency.
} 


\section{Exchange rate exposure}

For the past twenty years, ..nancial researchers have paid a great deal of attention to how to measure a ..rm's exposure to exchange rate movements. The basic models can be grouped into two categories: accounting - based exposure and stock price - based exposure. The studies by Claessens et al. (1998) and Allayannis (1996) belong to the ..rst group. They respectively use the percentage of exports on sales, and the ratio of net exports to sales as a measure of a ..rm's exposure to currency risk. In our framework, however, we encounter three problems with this methodology: ..rst, as Allayannis et al. (2000) show, exporting ..rms were the ones that hedged the most prior to the A sian crises of 1997. This means that the percentage of exports is not a good measure of exchange rate exposure for A sian countries. The second problem is lack of data. The number of ..rms for which data on exports is available is reduced in emerging markets ${ }^{6}$. Finally, it is possible that a ..rm that only operates in the domestic market is nonethel ess exposed to exchange rate risk, if competitors are foreign ..rms that sell to the country where the domestic ..rm operates ${ }^{7}$. Therefore, movements in the exchange rate axect the competitiveness of the domestic ..rm and therefore its pro..ts. A mong the studies that focus on stock price - based exposure, J orion (1990, 1991), Bodnar and Gentry (1993), and A mihud (1994) regress a company's stock return on exchange rate changes and additional control variables such as a market portfolio return ${ }^{8}$.

J orion (1991) uses a two-factor model, with the value-weighted stock market return as the ..rst factor and the orthogonal component of innovations in a trade-weighted exchange rate as the second factor. The orthogonalization eliminates spurious pricing of the exchange rate factor because of a possible correlation between exchange rate and market return.

F inally, Bodnar and Wong (2000) suggest that the inclusion of a market portfolio increases the precision of the residual exposure estimates. However, if the market portfolio has a non-zero exposure, including a market portfolio as a regressor shifts the distribution of the residual exposure estimates with respect to the total exposure counterparts. Therefore residual exposure estimates rełect the deviation of the ..rm's

\footnotetext{
${ }^{6}$ In their paper on the A sian crises of 1997, Allayannis et al. (2000) are able to ..nd data on exports only for the largest 50 companies in each country.
}

\footnotetext{
${ }^{7}$ For example, shipbuilders in C hina argued for a devaluation of the renminbi in 1998, since J apanese and South $\mathrm{K}$ orean shipbuilders became more competitive as a result of the 1997 crises (F inancial Times, J uly 6, 1998).

${ }^{8}$ In the early studies of Dumas (1978), Adler and Dumas (1984) and Hodder (1982), exposure was measured by the regression coec cient of the real value of the ..rm on the exchange rate. Although these models are easy to implement, they ..nd the percentage of ..rms with a signi..cant exposure to exchange rate movements to be low.
} 
exposure from the market's portfolio exposure. As most studies use a value-weighted portfolio, dominated by large ..rms with a more negative exposure to exchange rate movements, the residual exposure estimates suxer from a positive shift. The solution the authors suggest is the use of an equal-weight market portfolio to correct for the correlation between ..rm size and the sign of the exchange rate exposure.

\section{.1 A $n$ alternative approach}

We measure the exchange rate exposure by partly following the methodology in J orion (1991). However, our procedure is exactly the opposite of J orion's: in explaining individual companies' stock returns, we use as regressors the change in exchange rate and the component of market return that is orthogonal to the change in exchange rate. By using this methodology, we are able to circumvent the critique made by Bodnar and Wong (2000). Hence we are able to estimate which companies have a negative and positive exchange rate exposure in absolute sense, and hence do not have to rely on estimates of currency exposure that are calculated relative to the market as a whole.

First we estimate the following regression for each country in our sample:

$$
R_{m t}^{j}={ }_{0}^{\circ j}+{ }_{1}^{o j} R_{x t}^{j}+{ }^{o j} \quad 8 j=1 ; \ldots ; 18
$$

where $R_{m t}^{j}$ is the market return, and $R_{x t}^{j}$ is the change in the exchange rate in country $j$. We estimate the ${ }^{\circ}$ coes cients using monthly data from month $t=i 72$ to month $t=i 37$ relative to the currency depreciation month. Next, we calculate $F_{m t}^{j}=R_{m t}^{j} i\left(B_{o}^{j}+B_{1}^{j} R_{x t}^{j}\right)$ from the previous regression, and use the estimated orthogonal component of market return in the regression:

$$
R_{i j t}= \pm+{ }_{i}^{-x} R_{x t}^{j}+{ }^{-m} F_{m t}^{j}+{ }^{2} i j t
$$

where $R_{i j}$ is the stock return of ..rm i in country $j, R_{x}^{j}$ is the monthly change in the exchange rate in country $j$, and $F_{m}^{j}$ is the estimated orthogonal component for market $j$. The estimated ${ }_{i}^{-x}$ are, as stated, measures of ..rm i's exposure to exchange rate risk. Additionally, to avoid non-synchronous movements in exchange rates and stock returns, we use monthly data.

In Table II we show for each country the average exchange rate beta and the orthogonal market beta, as well as the each individual market exposure coed cient to exchange rate movements, following the methodology outlined above. The average exchange rate beta is the size-weighted average of the exchange rate betas calculated for the ..rms in a particular country. The market exposure is, for every country, the estimate of ${ }^{\circ}$ in the regression (1). 
Ten countries in our sample have a negative exchange rate exposure. All European countries, except Turkey, have a negative value for ${ }^{\circ}$, whereas in all A sian countries, except for the P hilippines and Thailand, ${ }_{1}$ is positive. In Thailand, for instance, the country exposure is i 7:042. Indonesia, in the other extreme, displays a country exposure of 4.607 .

\section{[Insert Table II]}

We expect exporting ..rms to display a negative exchange rate beta, while domestic ..rms should have a positive exposure. Seoul Foods, for instance, a South Korean ..rm that manufactures bread and snack foods (arguably a non-exporting ..rm) has a beta of 2:509. A n exporting ..rm such as Shin Corporation ${ }^{9}$, from Taiwan, has a beta of i 7:5041. The results for the average market betas are consistent with Bodnar and W ong (2000), since we ..nd markets to be exposed to currency movements.

Therefore, and in the absence of data on the structure of the balance sheet for each ...rm, we are able to characterize every ..rm in the sample into two categories depending on its exposure to exchange rate movements: ..rms that bene..t from currency depreciations, and ..rms that suxer from depreciations. It is worth noting, that exporting ..rms may have an insigni..cant exchange rate beta if they hedge their currency exposure. However, this is consistent with the argument in this paper: so exporting ..rms that hedge their currency exposure shouldn't have an incentive to increase their leverage prior to a currency crisis.

We rank ..rms in a particular country by their exchange rate beta. Firms are not comparable in terms of exchange rate exposure across countries. Therefore we rank each ...rm with respect to the other companies in the same country by splitting the sample between ..rms with negative and positive exchange rate beta.

In the next sections, we analyze the stock price reaction to a currency crisis, and the dixerent exects of the currency depreciation on ..rms depending on whether the ..rm has negative or positive exposure to currency movements.

\section{Stock price exects}

A good test of the outlined methodology is to analyze stock price exects around the currency depreciation for ...rms with positive and negative exchange rate beta. One expects ..rms with negative exchange rate beta

\footnotetext{
${ }^{9}$ Shiang Shin Corporation, located in Taiwan, is engaged in the manufacturing and exporting of Nitrile Gloves, Latex Surgical Gloves, Latex Examination Gloves, Vinyl Examination Gloves and other Disposable Medical Products. Its main markets are in the U.S.A., Europe, Australia, Japan, Central \& South A merica.
} 
to react positively to the currency crisis, since their revenues increase (either because they are exporting .rms, or because their competitors have an opposite exposure to the exchange rate).

We follow the standard procedure of estimating $B_{j t}=R_{i j t} i h_{i}+b_{i}^{m} R_{m j}$; where and $b_{i}^{m}$ are the estimates in the regression $R_{i j t}=\otimes_{+}+{ }^{-}{ }_{i} R_{m_{j} t}+{ }^{2} i j t$. The estimation is performed for a window running from $t=i 72$ to $t=i 36$ months relative to the depreciation month for each country. Results are reported in Table III, where we display cumulative abnormal returns for dixerent subperiods around the crises. For the overall sample $(4 ; 607 . . \mathrm{rms})$, the announcement return (two months around the date of the currency depreciation) is -6.7 , signi..cantly dixerent from zero at the one percent level. In Table IA, we report a 1.83 percent negative market return at $t=0$. A cross regions, the $C A R$ at from $t=i 1$ to $t=+1$ is $; 6: 55$ percent in European countries, -8.15 percent for the A sian economies, and -5.83 percent for Latin America; with the three coed cients signi...cant at the 1 percent level ${ }^{10}$. Harvey and Roper (1999) show that in A sian markets there is a consistent pattern of stock price declines prior to the devaluation. However, they focus on raw returns rather than CARs.

\section{[Insert Tabl e III]}

Interestingly, we ..nd a distinctive pattern of returns for negative and positive exchange rate beta ..rms in the period following the currency depreciation. For the whole sample, negative beta ..rms display a positive CAR of 373.24 percent, and a negative 92.73 percent for the group of positive exchange rate beta ..rms (only the former signi...cant at the one percent level). The same pattern is found in Europe: negative exchange rate beta ..rms bene.t and positive exchange rate beta ..rms suxer from the currency depreciation. Likewise, in A sia negative exchange rate beta ..rms are the ones that bene.t the most from the currency depreciation

\section{Firm leverage and exchange rate exposure}

In this section we empirically test the hypothesis that ..rms display increases in leverage prior to currency depreciations. Furthermore, we sort ..rms into two groups based on their exchange rate exposure. The rationale for dixerentiating between companies based on their currency exposure is that ..rms that bene..t from a currency depreciation may have an incentive to increase their leverage, because if the risks of high

\footnotetext{
${ }^{10} \mathrm{Additionally,} \mathrm{the} \mathrm{sample} \mathrm{of} \mathrm{E} \mathrm{uropean} \mathrm{..rms} \mathrm{include} \mathrm{a} \mathrm{majority} \mathrm{of} \mathrm{..rms} \mathrm{with} \mathrm{negative} \mathrm{exposure} \mathrm{to} \mathrm{exchange} \mathrm{rates.} B$ artov and Wong (2000) show that if the market portfolio has a non-zero exposure to exchange rate movements, the distribution of returns shift with respect to the total market exposure. Therefore, we expect negative CARs for European ..rms.
} 
leverage materialize, the ..rms expect a currency depreciation as a form of a bailout (see Bris and K oskinen, 2001).

We focus on a sample of countries that have suxered currency crises since 1985 and analyze the ..nancial policies of ..rms in those countries depending on their currency exposure. The testable hypothesis outlined above implies that, prior to a currency depreciation, we should observe an increase in corporate borrowing, and a decline in pro..tability.

We obtain data from Datastream on each ..rm's debt-to-value ratio ${ }^{11}$. The debt-to-value ratio is analyzed in the last three years preceding the currency devaluation, as well as two years after the devaluation. We gather data on a ..rm's total debt-to-value ratio, as well as on the percentage of short-term debt to total debt.

\section{[Insert Table IV ]}

[Insert Tabl e IV-B]

The Results are in Tables IV, IV-B and V. In Table IV we analyze changes in leverage prior to the crises; in Table IV-B we show the same results disaggregated at the country level. We..nd that ..rms that bene.tt from a currency depreciation (those with negative exchange rate beta) increase their debt-to-value ratios 3.42 percent in median (signi..cant at the one percent level) in the three-year period that precedes the devaluation, while..rms that suxer from a depreciation increase leverage by 3.55 percent (signi...cant at the one percent level). Negative exchange rate beta ..rms increase their leverage more than positive exchange rate beta ..rms in Europe (3.77 percent versus 1.4 percent) and Latin A merica (3.54 percent versus and insigni...cant 0.43 percent). The result is reversed for Asia, negative exchange rate beta ..rms increase their leverage by 2.69 percent; positive exchange rate beta ..rms do so by 4.25 percent. A twotailed Wilcoxon rank test reject the hypothesis that increments in leverage prior to a currency depreciation dixer for negative and positive exchange rate beta ..rms. However, we see that for E urope and A sia (and for the sample as a whole), the debt-to-value ratio is signi..cantly higher for negative exchange rate beta ..rms than for positive exchange rate beta ..rms three years prior to the devaluation, and the dixerence persists in the devaluation month.

In the two years that follow the devaluation, positive exchange rate beta ..rms increase their leverage signi..cantly more than negative exchange rate beta ..rms ( 2.15 percent for positive ER B ..rms; negative

\footnotetext{
${ }^{11} \mathrm{~T}$ hroughout the paper, we consider the debt-to-value ratio as the object of study. The results do not change qualitatively when we use the debt-to-equity ratio instead.
} 
ERB ..rms do not change their debt levels in the two years that follow the crises). This result is driven by Asian ..rms (3.58 percent for positive ERB ..rms; 1.58 for negative ERB ..rms). Leverage, however, continues to be higher for negative exchange rate beta ..rms, especially in Asia.

On country level, we ..nd that ..rms in Finland, Spain, UK, M exico and most Asian countries (with the exception of Thailand and Philippines) increase their leverage prior to a currency crisis (signi..cant increases at the $1 \%$ level) Finland and Korea have especially high leverage before their currencies were devalued (65.39\% and 58.68\% debt-to-value ratios, respectively), while in Sweden and Turkey the negative ERB ..rm had a considerable higher leverage than positive ERB ..rms.

\section{[Insert Table V]}

We also analyze the changes in short-term debt ratios. R esults are in Table V. For the overall sample, the median short-term debt to total debt ratio does not change signi..cantly around the currency depreciation. The countries in our sample were mostly ..nanced with short term debt prior to the crises. We ..nd short-term debt ratios of 62.63, 52.83 and 54.8 per cent in A sia, Europe and L atin A merica respectively.

Our results are consistent with Pomerleano (1998), Harvey and Roper (1999), and Claessens et al. (1998). Pomerleano (1998) documents the rapidly increasing debt ratios in A sia, specially short-term, from 1992 to 1996. However, he does not provide a disaggregated analysis by ..rm characteristics. Harvey and Roper (1999) report that the median leverage ratio across the 261 ..rms in their sample was 68.6 percent in 1992, and 114 percent in 1996. The leverage increase was mostly short-term again. In Claessens et al. (1998), A sian ..rms also display increasing debt ratios, and their data suggest that the ratio of short term debt to total debt in the A sian economies was signi..cantly larger than in the US or Germany (the median short-term debt share increases from 47.26 percent in 1988 to 60.43 percent in 1996; this ratio is 25.9 percent in 1996 in the US, 45.3 percent in Germany).

In general, these results con..rm that ..xed exchange rate economies display increasing corporate leverage prior to a currency depreciation, particularly among companies that bene..t from currency depreciations. To what extent the excess leverage induces currency crises will be the objective of Section V. In the next section we analyze alternative measures of performance, pro..tability and investment. 


\section{Other Variables}

\section{A Pro..tability}

Harvey and Roper (1999), Claessens et al. (1998), and Pomerleano (1998) report a signi..cant decline in pro..tability in A sian economies prior to the 1997 crises (decreasing R eturn on A ssets in Claessens et al., 1998; declining R eturn on Equity in Harvey and Roper, 1999; and decreasing Return on Equity and Return on Capital E mployed in Pomerleano, 1998). We want to examine whether this result extends to other regions and whether it is uniform across ..rms with dixerent characteristics.

\section{[Insert Table VI]}

We obtain data on two measures of pro..tability (E arnings B efore Interest and Taxes over Total Revenues, and Return on C apital E mployed). Results are in Tables VI and VII. We do ..nd signi..cant declines in pro..tability under both measures and in the three regions under consideration. For the overall sample, the EBIT to revenues ratio decreases by 13.57 percent. This decline is more severe for negative E RB (-15.08 against -8.18 per cent for positive ERB ..rms, signi..cantly dixerent at the 1 per cent level). The other measure of pro..tability we use, the return on capital employed, leads to the same conclusion: the ROCE decreases by 27.9 percent for the overall sample, 28.6 for negative ERB ..rms and 23.69 for positive ERB ..rms. Following the devaluation, both measures of pro..tability show that negative ERB ..rms perform better than positive ERB ..rms in A sia.

\section{[Insert Table VII]}

\section{B Financial Fragility}

Radelet and Sachs (1998) blame ..nancial panic as a cause of the E ast A sia crises of 1997. They identify the ratio of short-term debt to foreign exchange reserves as an indicator of a country's risk. Having short-term debt in excess of foreign exchange reserves could have triggered a crisis in the same way as in Diamond and Dybvig (1983) the inability of banks to face their short-term payments creates a bank run. R adelet and Sachs (1998) report that this ratio was above one for Indonesia, Thailand and South K orea prior to 1997. However, it was also below one for some other countries axected by the crises, such as Taiwan and the P hilippines.

We study ..nancial fragility in a similar fashion to R adelet and Sachs (1998), except that we use ..rm level data. In our analysis, the current ratio measures the ability of a creditor to pay ox its short-term 
debts. The current ratio is calculated as current assets to current liabilities, and it rełects the current liquidity of the ..rm. Pomerleano (1998) argues that this would be a good measure of a ..rm's ..nancial fragility, although the ratio is not reported in his study.

\section{[Insert Tabl e VIII]}

We report in Table VIII the current ratio for 2;907 ..rms in our sample. For the overall sample, the ratio falls from 1.38 to 1.33 in the three years preceding the corresponding crises (a signi..cant 4.57 percent in median), consistent with the country level results in Radelet and Sachs (1998). The evolution of the current ratio dixers across ..rms. While negative ERB ..rms decrease their current ratio by 4.8 percent (signi..cant at the 1 percent level), the change for positive ERB ..rms is insigni..cantly dixerent from zero.

For the US, the current ratio for the total sample of Compustat ..rms ( $5 ; 108$..rms with data available) in the years 1995 through 1998 is respectively 3.29, 3.70, 4.04, and 3.34. It compares to an average ratio of 1.33 for our total sample of 2; 907 ..rms at the onset of their respective crisis. So we can conclude that ..rms in countries that suxered currency crises showed early warnings of distress. It is also signi..cant that after the crises, ..rms' fragility increases even further (-3.43 percent for the overall sample, signi..cant at the 1 percent level), with positive ERB ..rms showing the worst performance (a signi..cant 7.91 decline against a 2.12 decline for negative ERB ), two years after the currency crises. The increase in ...nancial fragility after the crisis is due to Asian ..rms, while the ..rms in E urope show increasing current ratios.

\section{[Insert Table IX]}

Table IX complements the previous result. We display the interest coverage ratios for the ..rms in the sample, and ..nd a clear deterioration of the solvency of the exporting sector prior to the onset of the corresponding crises. For the overall sample, the interest coverage ratio decreases by 35.68 percent in the three years preceding the currency depreciation. Negative exchange rate beta ..rms experience a decrease of 37.21 percent in their interest coverage ratio, while ..rms with a positive exchange rate beta decrease their interest coverage ratio by 28.77; both coed cients are signi...cantly dixerent from zero at the 1 percent level. M ore importantly, we should note the situation of virtual bankruptcy of negative ERB A sian ..rms prior to the devaluation, with an interest coverage ratio of only 1.00 .

It is also interesting to note that for the overall sample, the interest coverage ratio increases (18.44 percent) during the two years following the currency crises. This result holds for both types of ..rms, 
but is larger for negative ERB ..rms (21.34 against a 6.44 percent increase). At the regional level, we observe important dixerences. While for A sian ..rms the interest coverage ratio deteriorates in the two years that follow the crises for both types of ..rms, in Latin A merica and E urope the increase in the interest coverage ratio is larger for positive ERB ..rms, although the dixerence is not signi..cant at the ten percent level. A nalysis of the interest coverage ratio reveals thus the special characteristics of the A sian crises with respect to the turbulences in Europe and Latin America.

\section{Investments}

We analyze the investment policies in our sample of ..rms from three dixerent regions by obtaining data on changes in total assets. In Table $\mathrm{X}$ we summarize changes in net investments measured by changes in total assets for a period of ...ve years.

\section{[Insert Table X]}

Overall, companies invest 62.41 percent less than they did before the onset of a currency crisis. Negative exchange rate beta ..rms have a larger decrease than positive exchange rate beta ..rms (67.46\% decline compared to $47.89 \%$ decline). Firms in Asian and Latin A merican countries display signi..cant higher investment rates compared to European ..rms. Claessens et al. (1998) report, in line with our results, relatively higher investment rates (measured as new dollar investments as a share of existing ..xed assets) in A sian ..rms than in U.S. and German ..rms.

\section{Summary of the ..ndings}

O ur analysis suggests that ..rms in countries that have suxered dramatic exchange rate depreciations in the last decade, follow a similar pattern of investment and ..nancial policies. We have documented a signi..cant decline in pro..tability in the corporate sector, that it is more accentuated for those ..rms with negative exposure to exchange rate movements. A lthough investment rates are declining, companies still increase the size of their total assets. This results suggests that corporations must rely on external ..nancing to engage in new investments. A s shown in Tables IV and V debt, either long- or short-term, is the more likely source of ..nancing. Whether debt ..nancing arises as an optimal instrument because of the underdevelopment of equity markets, or because ..rms ..nd it optimal to lever up when exchange rates are ..xed and devaluations are possible, will be studied in the next sections.

We document an increasing ...nancial fragility (measured by the ratio of current assets to current liabilities). Other studies have shown the same pattern (Pomerleano (1998), Harvey and Roper (1999)). 
Tables IX additionally shows a signi..cant decline in the coverage ratios in countries suxering currency depreciations.

In the next section we analyze ..rst whether micro variables (the ..rm's exposure to exchange rates being the most important one) axect the extent of a country's currency depreciation. Then we study cross-sectionally the determinants of a ..rm decision to rely on debt ..nancing when exchange rates are ..xed and depreciations are possible.

\section{Cross-sectional analysis}

\section{A Firm leverage and currency depreciations}

The argument made in B ris and Koskinen (2001) is that small, exporting countries where the corporate sector displays declining pro..tability, are more likely to suxer currency crises when the exchange rate is ..xed and the government cannot commit ex-ante not to let the currency depreciate. Firms in these ..rms tend to rely heavily on debt ..nancing, since through currency depreciation the costs of ..nancial distress are passed on to the economy as a whole.

We therefore test directly the previous hypothesis by focusing on the seventeen countries that suxered a currency crises included in our sample. The endogenous variable in our regressions is the exchange rate change in the two months that surround the currency crisis. The magnitude of this variable is obviously negative for the countries in our sample, and lower the more severe the crisis was. J ohnson et al. (2000) measure the severity of the A sian crises with the nominal exchange rate depreciation from the end of 1996 to J anuary 1999. The countries in our sample have relatively ..xed exchange rates over the sample period, so a better measure of the crises is the currency depreciation once the government support of the currency is abandoned. Secondly, using the debt-to-value ratio as an explanatory variable of the currency depreciation over a long horizon creates causality problems, that we avoid by measuring the currency depreciation in a dixerent subperiod. Finally, the amount of depreciation at $t=0$ is not a good measure of the total depreciation; South Korea, for instance, let the currency ‡oat three months after the ..rst speculative attacks against the won started (after repeated interventions by the Central Bank of K orea, South K orea abandoned its defense of the battered won on November 17, 1997). Additionally, most currencies depreciated dramatically in the months following the crisis ${ }^{12}$. We show the values of this

\footnotetext{
${ }^{12} \mathrm{~T}$ he Indonesian central bank widened the rupiah trading band from 12 percent to 8 percent in J uly 1997 . The band was .nally abandoned in A ugust 14, and in the next two months the rupiah lost 25:35 percent with respect to the dollar.
} 
variable in Table I. On average, depreciation amounts to 27.01 percent in a period of ...ve months.

The results in the previous sections show that countries that suxered currency crises display signi..cant increases in corporate debt-to-value ratios. We intend to analyze whether the corporate sector contributed to the severity of the crisis with high levels of leverage. We dixerentiate between ..rms with negative and positive exchange rate sensitivity by calculating the weighted average debt to equity ratio for ..rms in either group. That is, for every country we calculate:

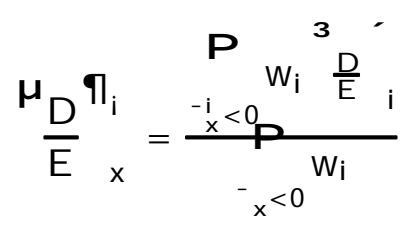

and similarly:

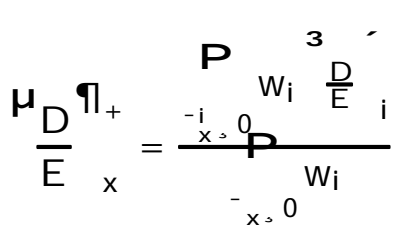

where ${ }_{x}^{-i}$ denotes a ..rm's exchange rate beta, and $w_{i}$ is the company's average sales in the three years that precede the corresponding currency crisis. Note that, within a country, the weighted average debt-to-equity ratio can be written as:

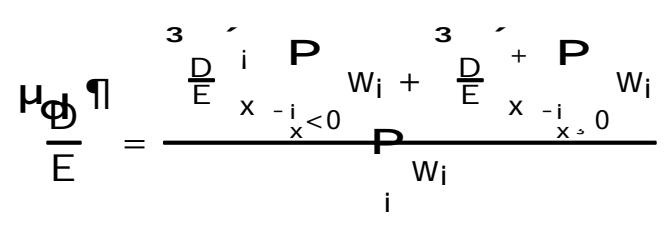

that is, we decompose the average leverage into two components: one attributable to ..rms with negative $E R B$, and the other corresponding to ..rms with positive ERB.

La Porta et al. (1998) argue that laws axecting investor protection have consequences for corporate ..nance. We therefore control in our analysis for dixerences in et ciency of the judicial system, rule of law, corruption, and risk of expropriation across countries. Those variables are averages calculated over dixerent time horizons, so their interpretation must be taken with caution. For instance, the ef ciency of the judiciary system is calculated by La Porta et al. as the average between 1980 and 1983, while the currency crises we consider date from 1992. In our regressions, we employ the complete time series of data that they use in their paper ${ }^{13}$, and calculate the ..ve year average prior to the corresponding currency crisis date. Comparing the mean values of the variables in our sample with all the countries considered by La Porta et al. (1998) we do not observe dramatic dixerences ( the mean values for the variables ' $E \phi$ ciency of

\footnotetext{
${ }^{13}$ We are grateful to F Iorencio López de Silanes for providing us with these unpublished data.
} 
the J udicial System', 'R ule of Law', 'Corruption', and 'Risk of Expropriation' are 7.10, 6.78, 6.59, and 7.96 for our sample, and 7.67, 6.85, 6.9, and 8.05, for a total sample of 49 countries). J ohnson et al. (2000) ..nd that these four measures of legal institutions predict the changes in exchange rates in emerging markets better than the standard macro measures. They report a negative relationship between these variables and the currency depreciation from 1997 to 1998 (low values for 'Corruption', and 'Risk of Expropriation' mean respectively high levels of corruption and expropriation risk). We control as well for the country's GDP. In terms of GDP, the recent currency crises have axected to relatively small European countries, and large A sian and Latin A merican E conomies.

\section{[Insert Table XI]}

We provide dixerent speci...cations due to the reduced number of degrees freedom. In Panel I we only make use of capital structure and corporate governance variables. The results in Models I and II provide empirical support to our claim that the relevant factor in explaining the severity of a currency crisis is not the average debt to value ratio, but the debt to value ratio for ..rms with negative exposure to exchange rate changes. Even when we control for the variables in La Porta et al. (1998), the average debt to value ratio is of the wrong sign (M odel III) or is only marginally signi..cant (M odel IV), whereas this parameter is signi..cant for negative ERB ..rms (at $10 \%$ level in Model V and at $1 \%$ level in Model VI).

In Panel II, we add two macroeconomic variables to our analysis, budget and current account de..cits relative to the GDP. We observe that the average debt to value ratio lacks explanatory power (M odels VIII and $X$ ); whereas the coed cient for the negative ERB debt to equity value is signi..cant at the 10 percent level in Model XII. The GDP and budget de..cit one year prior to the crises are signi..cantly dixerent from zero across dixerent model speci..cations. The results are mixed for the current account variable. We see in Table XI that the coe cients of the variables $E \phi$ ciency of the Judicial System, and Rule of Law are negative ${ }^{14}$, consistent with the results in J ohnson et al. (2000). We also ..nd that smaller countries depreciated their currencies the most.

\section{B Firm leverage and currency exposure}

We complete the cross-sectional analysis by testing whether ..rms' currency exposure measured by their exchange rate betas axects ..rms' ..nancing policies prior to a currency depreciation. If ..nancial distress

\footnotetext{
${ }^{14} \mathrm{~A}$ negative coec cient for a given variable implies that larger variables of that variable are associated with less severe currency depreciations.
} 
is likely to induce a government to let the currency depreciate as a way of bailing out companies, then we should expect ..rms that bene..t the most from a currency depreciation to have a higher leverage than companies that suxer from depreciation prior to a currency crisis.

We test this extreme by performing a regression analysis at the ..rm level where the explanatory variable is the ..rm's debt-to-value ratio (book values) as of December prior to the corresponding currency crisis. The set of explanatory variables includes the ..rm's exchange rate beta, calculated over a window of $\mathrm{t}=\mathrm{i} 60$ to $\mathrm{t}=\mathrm{i} 24$ months relative to the event month. We also use as explanatory variables the measures of corporate law from La Porta et al. (1998) described in the previous subsection. Rajan and Zingales (1995) argue that highly levered companies are more likely to give up pro..table investment opportunities. Hence, growth opportunities (proxied by the market value of assets divided by the book value of assets) should be negatively related to debt-to-equity ratios. We calculate the average market to book ratio in the three years preceding the currency crises for 4,232 ..rms in our sample.

In Rajan and Zingales (1995), size is measured by the logarithm of sales. They obtain a positive coed cient in their regressions, although, in their view, a negative relationship between size and debt levels is sensible if size is also a proxy for the information outside investors have. Our measure of size is a threeyear average of a ..rm's sales in the three years before the relevant currency depreciation. Additionally, and despite disagreeing theoretical predictions regarding the exect of pro..tability on leverage, they ..nd a negative relationship between EBITDA (normalized by the book value of assets) and book debt-to-value ratios. Our measure of pro..tability is EBIT normalized by total assets. We further control for the log of the GDP per capita in dollars.

\section{[Insert Tabl e XII]}

The results from the regression are reported in Table XII. For the total sample $(1.601$..rms with data available), we ..nd results consistent with Rajan and Zingales (1995), since pro..tability and size have respectively negative and positive coed cients in general. We also ..nd, consistent with the results in Tables IV and V, that A sian ..rms display, prior to the crises, relatively higher levels of debt than those in European and Latin American ..rms.

Finally, and focusing on the coet cient for the exchange rate beta, we consistently ..nd a negative relationship between a ..rm's exposure to exchange rate movements and book leverage. 


\section{Conclusion}

This paper uses company level data from seventeen countries that have suxered a currency crisis during the past decade. Companies are sorted into two groups depending on whether they bene.t from or are harmed by currency appreciations. The sorting is done using companies individual stock returns that are regressed on their home currency's movement against the U.S. dollar and on the part of market return that is orthogonal to the currency movement. Using this grouping we are able to show that there are dixerences in companies' leverage and pro..tability depending on their exchange rate beta. While leverage increases and pro..tability declines for all companies, these exects are more pronounced for negative exchange rate beta companies. Moreover, controlling for ..rm characteristics, the ..rms that bene.t from currency depreciations also have higher leverage prior to a crisis than ..rms that are harmed by currency depreciations. Finally, the amount of currency depreciation is positively related to leverage in companies that bene..t from depreciations.

Whether the corporate sector's choice between foreign and domestic debt axects the probability and the severity of currency crises is still an open question. The measure of leverage that is reported in this paper does not distinguish among dixerent sources of debt ..nancing. Neither does this paper consider the dixerence between debt issues and stock repurchases; both increase the debt-to-equity ratio. Disaggregated data on debt ..nancing for emerging and developing economies such as the ones that we consider are not easily available, so indirect measures are necessary. The analysis, however, would have interesting implications, and deserves further research. 


\section{References}

[1] A dler Michael, and Bernard Dumas, 1983: International Portfolio Choice and Corporation Finance: A Synthesis, The J ournal of Finance 38, 925-984.

[2] A ghion Philippe, Philippe Bachetta, and Abhijit Banerjee, 2000: Currency Crises and Monetary Policy in an Economy with Credit Constraints, CEPR Discussion Paper 2529.

[3] A llayannis G eorge, 1996: Exchange-R ate Exposure R evisited, DSW P 97-06, Darden School, University of Virginia.

[4] A llayannis George, Gregory W. B rown, and Leora K lapper, 2000: Exchange-R ate Risk M anagement. Evidence from East Asia, mimeo.

[5] A llen, F. and D. Gale ,2000, Optimal Currency Crises, Carnegie-Rochester Series on Public Policy, forthcoming.

[6] A mihud, Yakov, 1994: Exchange Rates and the Valuation of Equity Shares, in $Y$. Amihud and R M. Levich (eds.), Exchange Rates and Corporate Performance (Irwin, N ew York), 49-59.

[7] Bailey Warren, and Y. Peter Chung, 1995: Exchange R ate Fluctuations, Political Risk, and Stock R eturns: Some Evidence from an Emerging Market, J ournal of Financial and Quantitative Analysis 20, 541-561.

[8] Bartov Eli, and Gordon M. B odnar, 1994: Firm Valuation, Earnings Expectations, and the ExchangeR ate Exposure Exect, The J ournal of Finance 49, 1755-1785.

[9] Bodnar, Gordon M., and W. Gentry, 1993: Exchange rate exposure and industry characteristics: Evidence from Canada, J apan, and the U.S., J ournal of International M oney and Finance 12, 29-45.

[10] Bodnar, Gordon M., and M.H. Franco Wong, 2000: Estimating Exchange Rate Exposures: Some "W eighty" Issues. NBER Working Paper No. W 7497.

[11] B ris A rturo, and Yrjö K oskinen, 2001: Corporate Leverage and Currency Crises, forthcoming, J ournal of $F$ inancial $E$ conomics

[12] Caballero, Ricardo and Arvind Krishnamurthy, 1999: Emerging Markets Crises: An Asset Markets Perspective, mimeo. 
[13] Chang, Roberto and A ndres Velasco, 1998a, F inancial Fragility and the Exchange R ate R egime, NBER Working Paper No. 6469.

[14] Chang, Roberto and Andres Velasco, 1998b, Financial Crises in Emerging Markets: a Canonical Model, NBER Working Paper No. 6606.

[15] Claessens Stijn, Simeon Djankov and Larry Lang, 1998: East A sian Corporates: Growth, Financing and Risks over the Last Decade, Working Paper, World Bank.

[16] Corsetti, Giancarlo, Paolo Pesenti and N ouriel Roubini, 1998a: W hat Caused the A sian Currency and Financial Crisis? Part I: A Macroeconomic Overview, mimeo, Yale University.

[17] Corsetti, Giancarlo, Paolo Pesenti and Nouriel R oubini, 1998b: W hat Caused the A sian C urrency and Financial Crisis? Part II: The Policy Debate, mimeo, Yale University.

[18] Corsetti, Giancarlo, Paolo Pesenti and Nouriel Roubini, 1999, Paper Tigers? A Model of the A sian Crisis, European Economic Review, 43:1211-1236.

[19] Diamond, D.W. and P. Dybvig, 1983: Bank Runs, Deposit Insurance, and Liquidity, J ournal of Political Economy 91:401-419.

[20] Dumas, Bernard, and Bruno Solnik, 1995: The World Price of Foreign Exchange Risk, The J ournal of Finance $50,445-479$.

[21] Dumas B ernard, 1978: T he Theory of the Trading Firm R evisited. The J ournal of Finance 33, 10191030.

[22] Harvey, Campbell R. and Andrew H. Roper, 1999: The A sian B et, mimeo, Duke University.

[23] Hodder, J ames E., 1982: Exposure to Exchange-Rate M ovements, J ournal of International E conomics ,13(3-4), 375-86.

[24] J ohnson, Simon, Peter Boone, Alasdair Breach and Eric Friedman, 2000: Corporate Governance in the Asian Financial Crisis, J ournal of F inancial Economics 58, 141-186.

[25] J orion Philippe, 1990: The Exchange Rate Exposure of U.S. M ultinationals, J ournal of Business 63, 331-345.

[26] J orion Philippe, 1991: The Pricing of Exchange R ate Risk in the Stock M arket, J ournal of Financial and Quantitative Analysis 26, 363-376. 
[27] Kaminsky, Graciela and Carmen M. Reinhart, 1996: The twin crises: the causes of banking and balance-of payment problems, mimeo, Federal R eserve Board.

[28] La Porta, Rafael, Florencio López-de-Silanes, A ndrei Shleifer, and R obert W . Vishny, 1998: Law and Finance, J ournal of Political E conomy, December.

[29] M itton, Todd, 2001: A Cross-F irm A nalysis of the Impact of Corporate Governance on the E ast A sian Financial Crisis, forthcoming, J ournal of Financial Economics.

[30] OECD, 1999: A sia and the Global Crisis: The Industrial Dimension, Paris OECD.

[31] Pomerleano M ichael, 1998: The East Asia Crisis and Corporate Finances. The Untold Micro Story, E merging Markets Quarterly 2:4, 14-27

[32] R adelet, Steven and J exrey Sachs, 1998: The Onset of the East Asian F inancial Crisis, NBER W orking Paper No. 6680 .

[33] Rajan Raghuram G. and Luigi Zingales, 1995: W hat Do We Know about Capital Structure? Some E vidence from International Data, The J ournal of Finance 50, 1421-1460. 


\begin{tabular}{|c|c|c|c|c|c|c|c|c|}
\hline Country & $\begin{array}{l}\text { Devaluation } \\
\text { Month }(t=0)\end{array}$ & N. Obs. & $\begin{array}{l}\text { Firms in Main } \\
\text { Exchange }\end{array}$ & $\begin{array}{c}\text { Percent } \\
\text { in Sample }\end{array}$ & $\begin{array}{c}\text { Market } \\
\text { Return } \\
\mathbf{t}=0\end{array}$ & $\begin{array}{c}\text { Currency } \\
\text { Depreciation } \\
\mathbf{t}=0\end{array}$ & $\begin{array}{c}\text { Currency } \\
\text { Depreciation } \\
t=-2 \text { to } t=+2\end{array}$ & $\begin{array}{l}\text { Average } \\
\text { Leverage }\end{array}$ \\
\hline Total & & 3,617 & 7,729 & $46.80 \%$ & $-1.83 \%$ & $-19.31 \%$ & $-27.01 \%$ & $51.20 \%$ \\
\hline Brazil & March, 1995 & 15 & 570 & $2.63 \%$ & $-13.09 \%$ & $-46.29 \%$ & $-94.70 \%$ & $25.15 \%$ \\
\hline Mexico & December, 1994 & 29 & 206 & $14.08 \%$ & $-4.54 \%$ & $-35.03 \%$ & $-42.47 \%$ & $39.39 \%$ \\
\hline Venezuela & December, 1995 & 7 & 159 & $4.40 \%$ & $8.37 \%$ & $-41.52 \%$ & $3.56 \%$ & $29.95 \%$ \\
\hline United Kingdom & September, 1992 & 1,191 & 2,440 & $48.81 \%$ & $-3.38 \%$ & $-8.41 \%$ & $-15.85 \%$ & $29.34 \%$ \\
\hline Spain & May, 1993 & 88 & 379 & $23.22 \%$ & $4.86 \%$ & $-8.64 \%$ & $-10.88 \%$ & $43.16 \%$ \\
\hline Finland & September, 1992 & 24 & 62 & $38.71 \%$ & $-15.74 \%$ & $-14.17 \%$ & $-13.22 \%$ & $59.97 \%$ \\
\hline Italy & September, 1993 & 14 & 259 & $5.41 \%$ & $8.27 \%$ & $-3.24 \%$ & $-11.42 \%$ & $42.49 \%$ \\
\hline Norway & December, 1992 & 49 & 123 & $39.84 \%$ & $15.72 \%$ & $-7.88 \%$ & $-20.31 \%$ & $50.33 \%$ \\
\hline Sweden & November, 1992 & 82 & 205 & $40.00 \%$ & $5.11 \%$ & $-19.84 \%$ & $-31.35 \%$ & $28.18 \%$ \\
\hline Turkey & March, 1994 & 37 & 176 & $21.02 \%$ & $14.65 \%$ & $-55.05 \%$ & $-72.13 \%$ & $50.77 \%$ \\
\hline Indonesia & August, 1997 & 165 & 281 & $58.72 \%$ & $-8.35 \%$ & $-17.80 \%$ & $-34.02 \%$ & $52.57 \%$ \\
\hline South Korea & November, 1997 & 713 & 776 & $91.88 \%$ & $-17.25 \%$ & $-49.84 \%$ & $-54.64 \%$ & $75.18 \%$ \\
\hline Malaysia & July, 1997 & 367 & 703 & $52.20 \%$ & $-6.08 \%$ & $-9.42 \%$ & $-16.99 \%$ & $38.21 \%$ \\
\hline Philippines & July, 1997 & 153 & 221 & $69.23 \%$ & $-4.68 \%$ & $-9.09 \%$ & $-19.72 \%$ & $28.96 \%$ \\
\hline Singapore & July, 1997 & 209 & 334 & $62.57 \%$ & $-4.77 \%$ & $-5.05 \%$ & $-4.86 \%$ & $36.23 \%$ \\
\hline Taiwan & October, 1997 & 320 & 404 & $79.21 \%$ & $-7.65 \%$ & $-7.97 \%$ & $-14.23 \%$ & $34.03 \%$ \\
\hline Thailand & July, 1997 & 154 & 431 & $35.73 \%$ & $29.46 \%$ & $-22.16 \%$ & $-27.31 \%$ & $55.43 \%$ \\
\hline
\end{tabular}

\section{Table IA. Sample Description.}

This table displays the number of firms in the sample, number of firms in the corresponding exchange, market return in the devaluation month, and currency depreciation in the crisis month and around the crisis month; and average leverage. Average leverage is the weighted average (by size) of the debt-to-value ratio for all firms in each country. The sample includes all firms with available information in Datastream for seventeen countries that have suffered a currency crises in the period 1985-2000. Stock returns, Exchange rates, Market Returns and accounting variables are from Datastream. The number of firms in the main exchange is as of December of the corresponding crisis year, and it is obtained from the International Federation of Stock Exchanges' web page, at www.fibv.com/stats/ta11.xls. 


\begin{tabular}{|c|c|}
\hline Brazil & Fixed against the dollar six months before the crisis. \\
\hline Spain & $\begin{array}{l}\text { The exchange rate is maintained within a margin of } \pm 15 \text { percent around the bilateral central rates against other } \\
\text { participating currencies, with the exception of Germany and the Netherlands, in which case the exchange rate is } \\
\text { maintained within a margin of } \pm 2.25 \text { percent. }\end{array}$ \\
\hline Finland & Unilaterally pegged to Ecu. \\
\hline Indonesia & $\begin{array}{l}\text { Explicit real exchange rate targeting with the nominal rate falling from } 1900 \text { rupieh to the US } \$ \text { in } 1990 \text { to } 2400 \text { by the } \\
\text { beginning of } 1997\end{array}$ \\
\hline South Korea & $\begin{array}{l}\text { The Korean won followed periods of fixity to the US } \$ \text { but had a more flexible exchange } \\
\text { rate regime. The Won depreciated in nominal terms from } 1990 \text { until the beginning of } 1993 \text { (from } 700 \text { to almost } 800 \text { won } \\
\text { per dollar). Next, it traded in a very narrow range of } 800 \text { to } 770 \text { won/ } \$ \text { between the beginning of } 1993 \text { and the middle of } \\
\text { 1996. Then, it started to depreciate by about } 10 \% \text { reaching a rate of } 884 \text { at the end of } 1996\end{array}$ \\
\hline Mexico & Fixed peso-dollar exchange rate \\
\hline Malaysia & A $10 \%$ range of 2.7 to 2.5 ringitt to the US\$ for most of the years between 1990 and the beginning of 1997 \\
\hline Norway & $\begin{array}{l}\text { The krone was first pegged to the Ecu on October 19, 1990, within a margin of } \pm 2.25 \text { per cent from a fixed rate of } \\
\text { NKr7.9940 per Ecu. }\end{array}$ \\
\hline Philippines & $\begin{array}{l}\text { The Peso fluctuated in a } 15 \% \text { range of } 28 \text { to } 24 \text { between } 1990 \text { and the beginning of } 1995 \text { but was } \\
\text { practically fixed at a } 26.2 \text { rate to the US dollar from the spring of } 1995 \text { until the beginning of } 1997\end{array}$ \\
\hline Sweden & Behaved as an ERM country, although not officially in the system. \\
\hline Singapore & $\begin{array}{l}\text { The currency actually appreciated in nominal terms throughout the 1990s going from a rate of } 1.7 \text { in } 1990 \text { to a rate of } 1.4 \\
\text { by the end of } 1996 .\end{array}$ \\
\hline Italy & $\begin{array}{l}\text { The exchange rate is maintained within a margin of } \pm 15 \text { percent around the bilateral central rates against other } \\
\text { participating currencies, with the exception of Germany and the Netherlands, in which case the exchange rate is } \\
\text { maintained within a margin of } \pm 2.25 \text { percent. }\end{array}$ \\
\hline Taiwan & $\begin{array}{l}\text { Real exchange rate targeting allowing its currency to fall from a rate of } 24 \text { New Taiwan dollars per US } \$ \text { in } \\
1990 \text { to a rate of } 27.8 \text { by the end of } 1996 .\end{array}$ \\
\hline Thailand & The Thai Bath was effectively fixed in a narrow 25.2 to 25.6 to the US\$ from 1990 until 1997 \\
\hline Turkey & Managed floating exchange rate. \\
\hline United Kingdom & $\begin{array}{l}\text { The exchange rate is maintained within a margin of } \pm 15 \text { percent around the bilateral central rates against other } \\
\text { participating currencies, with the exception of Germany and the Netherlands, in which case the exchange rate is } \\
\text { maintained within a margin of } \pm 2.25 \text { percent. }\end{array}$ \\
\hline Venezuela & The exchange rate is maintained within margins of \pm 7.5 percent. \\
\hline
\end{tabular}

\section{Table IB}

Exchange Rate Regimes in countries that have suffered Currency Crises

The Table describes the Exchange Rate Regimes of seventeen countries that have suffered currency crises since 1990. The description corresponds to the regime prevailing one month prior to the last currency depreciation considered in Table 1.

Source: Nouriel Roubini, "An Introduction to Open Economy Macroeconomics. Currency Crises and the Asian Crisis", in http://www.stern.nyu.edu/ nroubini/NOTES/macro5.htm\#9, and Lexis-Nexis 


\begin{tabular}{|c|c|c|c|c|c|c|c|c|}
\hline \multirow[t]{2}{*}{ Country } & \multirow[t]{2}{*}{$\mathbf{N}$} & \multirow{2}{*}{$\begin{array}{c}\text { Average } \\
\text { Exchange Rate } \\
\text { Beta }\end{array}$} & \multirow{2}{*}{$\begin{array}{c}\text { Average } \\
\text { Market } \\
\text { Beta }\end{array}$} & \multirow[t]{2}{*}{$\begin{array}{l}\text { Country } \\
\text { Exposure }\end{array}$} & \multicolumn{2}{|c|}{$\begin{array}{c}\text { Negative } \\
\text { Exchange Rate Beta }\end{array}$} & \multicolumn{2}{|c|}{$\begin{array}{c}\text { Positive } \\
\text { Exchange Rate Beta }\end{array}$} \\
\hline & & & & & $\%$ Firms & \% Significant & $\%$ Firms & \% Significant \\
\hline Total & 3,617 & 0.301 & 0.814 & & $53.71 \%$ & $4.15 \%$ & $46.29 \%$ & $5.02 \%$ \\
\hline Brazil & 15 & -1.362 & -0.991 & -1.322 & $33.33 \%$ & $20.83 \%$ & $66.67 \%$ & $13.16 \%$ \\
\hline Mexico & 29 & 21.040 & 0.369 & -2.221 & $82.76 \%$ & $10.00 \%$ & $17.24 \%$ & $16.00 \%$ \\
\hline Venezuela & 7 & 0.925 & 0.523 & 2.259 & $0.00 \%$ & $0.00 \%$ & $100.00 \%$ & $42.86 \%$ \\
\hline United Kingdom & 1,191 & -0.030 & 0.959 & -0.472 & $84.89 \%$ & $9.97 \%$ & $15.11 \%$ & $6.13 \%$ \\
\hline Spain & 88 & 2.580 & 0.926 & -0.821 & $64.77 \%$ & $5.45 \%$ & $35.23 \%$ & $10.53 \%$ \\
\hline Finland & 24 & 0.010 & 1.059 & -0.201 & $66.67 \%$ & $21.05 \%$ & $33.33 \%$ & $15.79 \%$ \\
\hline Italy & 14 & -0.380 & 0.896 & -0.263 & $71.43 \%$ & $9.38 \%$ & $28.57 \%$ & $13.82 \%$ \\
\hline Norway & 49 & -0.350 & 0.941 & -0.621 & $69.39 \%$ & $10.00 \%$ & $30.61 \%$ & $6.25 \%$ \\
\hline Sweden & 82 & -0.200 & 0.852 & -1.189 & $78.05 \%$ & $10.91 \%$ & $21.95 \%$ & $20.75 \%$ \\
\hline Turkey & 37 & -0.470 & 1.080 & 0.897 & $10.81 \%$ & $14.29 \%$ & $89.19 \%$ & $7.04 \%$ \\
\hline Indonesia & 165 & 1.710 & 0.911 & 4.607 & $28.48 \%$ & $35.42 \%$ & $71.52 \%$ & $6.67 \%$ \\
\hline South Korea & 713 & 0.050 & 0.738 & 1.262 & $79.24 \%$ & $9.71 \%$ & $20.76 \%$ & $2.30 \%$ \\
\hline Malaysia & 367 & 0.890 & 1.152 & 0.633 & $44.96 \%$ & $0.69 \%$ & $55.04 \%$ & $6.25 \%$ \\
\hline Philippines & 153 & -0.340 & 0.516 & -0.695 & $37.25 \%$ & $11.90 \%$ & $62.75 \%$ & $7.46 \%$ \\
\hline Singapore & 209 & -0.820 & 0.835 & 0.228 & $83.25 \%$ & $10.71 \%$ & $16.75 \%$ & $19.47 \%$ \\
\hline Taiwan & 320 & 0.260 & 0.897 & 0.853 & $68.13 \%$ & $9.09 \%$ & $31.88 \%$ & $3.57 \%$ \\
\hline Thailand & 154 & 1.140 & 0.821 & -7.042 & $9.09 \%$ & $15.14 \%$ & $90.91 \%$ & $9.52 \%$ \\
\hline
\end{tabular}

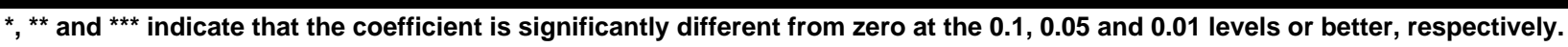

\section{Table II. Exchange rate beta.}

The third and fourth columns of this table display the average exchange rate beta and market beta for countries that have suffered a currency crises in the period 1985-2000. The fifth column displays the country exposure coefficient to exchange rate movements. This coefficient is calculated as follows. For every country in our sample, we estimate the regression $R_{m t}=\gamma_{o}+\gamma_{1} R_{s t}+\mathrm{v}_{s t}$, where $R_{m t}$ is the corresponding market return, and $R_{s t}$ is the change in the exchange rate for the same period. We estimate the $\gamma$ coefficients using monthly data from month $\mathrm{t}=-72$ to month $\mathrm{t}=-37$ relative to the currency depreciation month. The last four columns show the percentage of positive and negative ERB firms for each country and for the sample as a whole. Stock returns, Exchange rates, Market Returns and accounting variables are from Datastream. 


\begin{tabular}{|c|c|c|c|c|c|c|c|c|c|c|}
\hline \multirow[b]{2}{*}{ Region } & \multirow{2}{*}{$\begin{array}{l}\text { Exchange } \\
\text { Rate } \\
\text { Beta }\end{array}$} & \multirow[b]{2}{*}{$\mathbf{N}$} & \multicolumn{2}{|c|}{ From $t=-36$ to $t=-13$} & \multicolumn{2}{|c|}{ From $t=-12$ to $t=-2$} & \multicolumn{2}{|c|}{ From $t=-1$ to $t=+1$} & \multicolumn{2}{|c|}{ From $t=+2$ to $t=+36$} \\
\hline & & & CAR & p-value & CAR & p-value & CAR & p-value & CAR & p-value \\
\hline \multirow[t]{3}{*}{ Total } & & 4,607 & $-15.95 \%^{\star \star * \star}$ & $(<0.0001)$ & $31.83 \%^{\star \star \star}$ & $(<0.0001)$ & $-6.70 \%{ }^{\star \star \star}$ & $(<0.0001)$ & $58.96 \% \%^{\star \star \star}$ & $(<0.0001)$ \\
\hline & Negative & 3,103 & $27.08 \%$ *** & $(<0.0001)$ & $223.53 \%$ *** & $(<0.0001)$ & $-40.84 \%^{* * *}$ & $(<0.0001)$ & $373.24 \%^{* * *}$ & $(<0.0001)$ \\
\hline & Positive & 1,501 & $-36.72 \%$ *** & $(<0.0001)$ & $-60.70 \%$ *** & $(<0.0001)$ & $9.78 \% * * \star$ & $(<0.0001)$ & $-92.73 \%^{* * *}$ & $(<0.0001)$ \\
\hline \multirow[t]{3}{*}{ Europe } & & 2,150 & $-12.70 \%^{\star \star \star \star}$ & $(<0.0001)$ & $36.64 \%^{* \star *}$ & $(<0.0001)$ & $-6.55 \% \%^{\star \star \star}$ & $(<0.0001)$ & 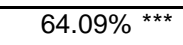 & $(<0.0001)$ \\
\hline & Negative & 1,705 & $35.40 \%$ *** & $(<0.0001)$ & $243.37 \%$ *** & $(<0.0001)$ & $-42.88 \%$ *** & $(<0.0001)$ & $400.64 \%^{* * *}$ & $(<0.0001)$ \\
\hline & Positive & 445 & $-36.91 \%$ *** & $(<0.0001)$ & $-67.39 \%$ *** & $(<0.0001)$ & $11.74 \%^{* * *}$ & $(<0.0001)$ & $-105.26 \%$ *** & $(<0.0001)$ \\
\hline \multirow[t]{3}{*}{ Asia } & & 2,335 & $-46.04 \%^{\star * \star}$ & $(<0.0001)$ & $-12.86 \% \%^{* \star *}$ & $(<0.0001)$ & $-8.15 \% \%^{\star * \star}$ & $(<0.0001)$ & $11.74 \%^{* \star \star}$ & $(0.0030)$ \\
\hline & Negative & 1,330 & $-80.89 \%$ *** & $(<0.0001)$ & $-33.67 \%$ *** & $(<0.0001)$ & $-14.53 \%$ *** & $(<0.0001)$ & $18.47 \%$ *** & $(0.0025)$ \\
\hline & Positive & 1,005 & $-35.04 \%$ *** & $(<0.0001)$ & $-6.30 \%{ }^{* * *}$ & $(0.0008)$ & $-6.14 \%{ }^{* * *}$ & $(<0.0001)$ & $9.61 \%$ * & $(0.0905)$ \\
\hline \multirow[t]{3}{*}{ Latin America } & & 119 & $-51.97 \%^{\star * \star}$ & $(<0.0001)$ & $-10.82 \%{ }^{* \star *}$ & $(0.0045)$ & $-5.83 \%{ }^{* \star *}$ & $(<0.0001)$ & $-74.27 \%^{* \star *}$ & $(<0.0001)$ \\
\hline & Negative & 68 & $-17.43 \%$ ** & $(0.0153)$ & $-4.96 \%$ & $(0.2787)$ & $-5.11 \%{ }^{* \star *}$ & $(0.0001)$ & $-6.28 \%$ & $(0.6228)$ \\
\hline & Positive & 51 & $-66.08 \%$ *** & $(<0.0001)$ & $-13.21 \%$ ** & $(0.0292)$ & $-6.12 \%$ *** & $(0.0016)$ & $-102.02 \%$ *** & $(<0.0001)$ \\
\hline
\end{tabular}

${ }^{\star \star}$ and ${ }^{\star \star \star}$ indicate that the coefficient is significantly different from zero at the $0.1,0.05$ and 0.01 levels or better, respectively.

\section{Table III. Stock Market Effect.}

This table displays the Cumulative Abnormal Returns from 72 months prior to the currency depreciation up to 36 months after the crisis, for a sample of firms in countries that have suffered a currency crises in the period 1985-2000. Cumulative Abnormal Returns are value weighted, with weights determined by the average market value (in dollars) from $\mathrm{t}=-72$ to $\mathrm{t}=-36$ relative to the crises date. 'Europe' includes firms from Finland, Norway, Spain, Sweden, Turkey and the United Kingdom. 'Asia' includes firms from Indonesia, Korea, Malaysia, Philippines, Singapore, Taiwan and Thailand. 'Latin America' includes firms from Brazil, Mexico, and Venezuela. Firms are divided into two groups base on their exchange rate beta, which is calculated as follows: for every country in our sample, we estimate the regression $R_{m t}=\gamma_{o}+\gamma_{1} R_{s t}+v_{s t}$, where $R_{m t}$ is the

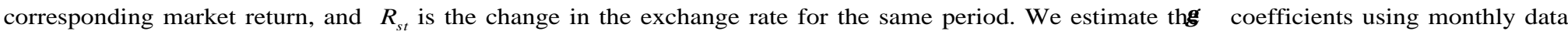
from month $t=-72$ to month $t=-37$ relative to the currency depreciation month. Next, we estimate $F_{m t}=R_{m t}-\left(\hat{\gamma}_{o}+\hat{\gamma}_{1} R_{s t}\right)$ from the previous regression, and use the estimated residual in the regression $R_{i j t}=\delta_{o}+\beta_{i}^{s} R_{s_{j} t}+\beta_{i}^{m} F_{m_{j} t}+\varepsilon_{i j t}$, where $R_{i j}$ is the stock return of firm $I$ in the country $j$, $R_{s j}$ is the monthly change in the exchange rate in the country $j$, and $F_{m_{j}}$ is the residual for market $j$. The measure of firm i's exposure to exchange rate risk is $\beta_{\mathrm{i}}^{\mathrm{s}}$.Stock returns, Exchange rates, Market Returns and accounting variables are from Datastream. 


\begin{tabular}{|c|c|c|c|c|c|c|c|c|c|c|c|c|c|c|c|c|c|}
\hline \multirow[b]{2}{*}{ Region } & \multirow{2}{*}{$\begin{array}{c}\text { Exchange Rate } \\
\text { Beta }\end{array}$} & \multirow[b]{2}{*}{$\mathbf{N}$} & \multirow[b]{2}{*}{$t=-3$} & \multirow[b]{2}{*}{$t=-2$} & \multirow{2}{*}{\multicolumn{2}{|c|}{$t=-1$}} & \multirow{2}{*}{\multicolumn{2}{|c|}{$t=0$}} & \multirow{2}{*}{\multicolumn{2}{|c|}{$t=+1$}} & \multirow{2}{*}{\multicolumn{2}{|c|}{$t=+2$}} & & \multicolumn{2}{|c|}{ From $t=-3$ to $t=0$} & \multicolumn{2}{|c|}{ From $t=0$ to $t=+2$} \\
\hline & & & & & & & & & & & & & & $\%$ Change & p-value & $\%$ Change & $p$-value \\
\hline \multirow[t]{3}{*}{ Total } & & 3,617 & $31.51 \%$ & $33.78 \%$ & & $35.48 \%$ & & $37.11 \%$ & & $40.48 \%$ & & $37.89 \%$ & & $3.45 \%$ *** & $(<0.0001)$ & $0.94 \%$ *** & $(<0.0001)$ \\
\hline & Negative & 2,465 & $32.43 \%$ & $35.07 \%$ & & $37.50 \%$ & & $38.27 \%$ & & $41.52 \%$ & & $38.27 \%$ & & $3.42 \%$ *** & $(<0.0001)$ & $0.00 \% * * *$ & $(<0.0001)$ \\
\hline & Positive & 1,152 & $\begin{array}{l}29.08 \% \\
(0.0004)\end{array}$ & $\begin{array}{l}30.07 \% \\
(<0.0001)\end{array}$ & $* * *$ & $\begin{array}{l}31.03 \% \\
(<0.0001)\end{array}$ & $* * *$ & $\begin{array}{c}34.64 \% \\
(<0.0001)\end{array}$ & $* * *$ & $\begin{array}{l}37.89 \% \\
(0.0054)\end{array}$ & $* * *$ & $\begin{array}{l}37.50 \% \\
(0.3662)\end{array}$ & & $\begin{array}{l}3.55 \% \text { *** } \\
(0.7633)\end{array}$ & $(<0.0001)$ & $\begin{array}{r}2.15 \% \%^{* * *} \\
(<0.0001)^{* * *}\end{array}$ & $(<0.0001)$ \\
\hline \multirow[t]{3}{*}{ Europe } & & 1,403 & $27.01 \%$ & $31.03 \%$ & & $31.51 \%$ & & $31.03 \%$ & & $31.03 \%$ & & $30.07 \%$ & & $3.57 \%$ *** & $(<0.0001)$ & $0.00 \%$ & $\overline{(0.6077)}$ \\
\hline & Negative & 1,132 & $27.54 \%$ & $31.03 \%$ & & $31.97 \%$ & & $31.51 \%$ & & $31.51 \%$ & & $30.07 \%$ & & $3.77 \%$ *** & $(<0.0001)$ & $0.00 \%$ & (0.6394) \\
\hline & Positive & 271 & $\begin{array}{r}23.08 \% \\
(0.3834)\end{array}$ & $\begin{array}{l}27.80 \% \\
(0.0444)\end{array}$ & ** & $\begin{array}{l}28.06 \% \\
(0.0350)\end{array}$ & ** & $\begin{array}{l}29.82 \% \\
(0.2587)\end{array}$ & & $\begin{array}{l}29.08 \% \\
(0.2947)\end{array}$ & & $\begin{array}{l}28.06 \% \\
(0.3779)\end{array}$ & & $\begin{array}{l}1.40 \% \text { ** } \\
(0.3118)\end{array}$ & $(0.0122)$ & $\begin{array}{r}0.00 \% \\
(0.8678)\end{array}$ & $(0.8319)$ \\
\hline \multirow[t]{4}{*}{ Asia } & & 2,081 & $37.89 \%$ & $37.89 \%$ & & $40.48 \%$ & & $42.53 \%$ & & $48.98 \%$ & & $46.81 \%$ & & $3.32 \%{ }^{* * *}$ & $(<0.0001)$ & $2.28 \% \%^{* * *}$ & $\overline{(<0.0001)}$ \\
\hline & Negative & 1,240 & $41.52 \%$ & $41.86 \%$ & & $45.95 \%$ & & $46.81 \%$ & & $53.05 \%$ & & $49.50 \%$ & & $2.69 \%$ *** & $(<0.0001)$ & $1.58 \%$ *** & $(<0.0001)$ \\
\hline & Positive & 841 & $31.51 \%$ & $31.51 \%$ & & $33.33 \%$ & & $37.11 \%$ & & $42.53 \%$ & & $43.18 \%$ & & $4.25 \%$ *** & $(<0.0001)$ & $3.84 \%$ *** & $(<0.0001)$ \\
\hline & & & $(<0.0001) * * *$ & $(<0.0001)$ & $* * *$ & $(<0.0001)$ & $* * *$ & $(<0.0001)$ & $* * *$ & $(<0.0001)$ & $* \star \star *$ & $(0.0002)$ & 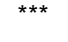 & $(0.2827)$ & & $(0.0010) * * *$ & \\
\hline \multirow[t]{3}{*}{ Latin America } & & 133 & $22.78 \%$ & $20.00 \%$ & & $21.88 \%$ & & $23.94 \%$ & & $26.20 \%$ & & $28.57 \%$ & & $2.65 \%$ * & $(0.0567)$ & $4.45 \%{ }^{* * *}$ & $\overline{(0.0002)}$ \\
\hline & Negative & 93 & $24.81 \%$ & $21.57 \%$ & & $23.08 \%$ & & $27.79 \%$ & & $29.58 \%$ & & $31.97 \%$ & & $3.54 \%$ ** & $(0.0486)$ & $4.46 \%$ *** & $(0.0007)$ \\
\hline & Positive & 40 & $\begin{array}{r}20.64 \% \\
(0.4026)\end{array}$ & $\begin{array}{c}17.36 \% \\
(0.1656)\end{array}$ & & $\begin{array}{c}17.01 \% \\
(0.1260)\end{array}$ & & $\begin{array}{l}21.26 \% \\
(0.2180)\end{array}$ & & $\begin{array}{l}20.00 \% \\
(0.3386)\end{array}$ & & $\begin{array}{l}21.26 \% \\
(0.1982)\end{array}$ & & $\begin{array}{r}0.43 \% \\
(0.7748)\end{array}$ & $(0.6296)$ & $\begin{array}{r}0.42 \% \\
(0.5781)\end{array}$ & $(0.1379)$ \\
\hline
\end{tabular}

Table IV. Debt to Value Ratio.

This table displays the median Debt to Value Ratio for a sample of firms in countries that have suffered a currency crises in the period 1985-2000. 'Europe' includes firms from Finland, Italy, Norway, Spain, Sweden, Turkey and the United Kingdom. 'Asia' includes firms from Indonesia, Korea, Malaysia, Philippines, Singapore, Taiwan and Thailand. 'Latin America' includes firms from Brazil, Mexico, and Venezuela. The ratio equals Total Debt to Value (book value of equity plus debt). Firms are divided into two groups base on their exchange rate beta, which is calculated as follows: for every country in our sample, we estimate the regression $R_{m t}=\gamma_{o}+\gamma_{1} R_{s t}+v_{s t}$, where $R_{m t}$ is the corresponding market return, and $R_{s t}$ is the change in the exchange rate for the same period. We estimate the $\gamma$ coefficients using monthly data from month $t=-72$ to month $t=-37$ relative to the currency depreciation month. Next, we estimate $F_{m t}=R_{m t}-\left(\hat{\gamma}_{o}+\hat{\gamma}_{1} R_{s t}\right)$ from the previous regression, and use the estimated residual in the regression $R_{i j t}=\delta_{o}+\beta_{i}^{s} R_{s_{j} t}+\beta_{i}^{m} F_{m_{j} t}+\varepsilon_{i j t}$, where $R_{i j}$ is the stock return of firm I in the country $j$, Ris the monthly change in the exchange rate in the country $j$, and $F_{m_{j}}$ is the residual for market $j$. The measure of firm i's exposure to exchange rate risk $\beta_{i}^{s}$. Tests of significance are based on a Wilcoxon signed rank test. We also include the p-value for a test of equal medians between negative and positive exchange rate beta firms. This test is based on a two-tailed Wilcoxon rank test. 


\begin{tabular}{|c|c|c|c|c|c|c|c|c|c|c|c|c|c|}
\hline \multirow{3}{*}{$\begin{array}{l}\text { Country } \\
\text { Finland }\end{array}$} & \multirow{2}{*}{$\begin{array}{c}\text { Exchange Rate } \\
\text { Beta }\end{array}$} & \multirow[b]{2}{*}{$\mathbf{N}$} & \multirow[b]{2}{*}{$=-3$} & \multirow[b]{2}{*}{$t=-2$} & \multirow[b]{2}{*}{$t=-1$} & \multirow[b]{2}{*}{$t=0$} & \multirow[b]{2}{*}{$t=+1$} & \multirow[b]{2}{*}{$t=+2$} & & rom & $t=-3$ to $t=0 \mathrm{~F}$ & om $\mathrm{t}=0$ to $\mathrm{t}=+2$ & \\
\hline & & & & & & & & & \% Chang & ge & $p$-value ${ }^{\circ}$ & Change & p-value \\
\hline & & 24 & $51.33 \%$ & $55.56 \%$ & $60.94 \%$ & $65.39 \%$ & $58.51 \%$ & $55.95 \%$ & $13.19 \%$ * & $\star \star \star \star ~$ & $(0.0059)$ & $-0.32 \%$ & (0.4038) \\
\hline & Negative & 16 & $42.71 \%$ & $54.96 \%$ & $64.66 \%$ & $70.84 \%$ & $58.51 \%$ & $56.14 \%$ & $17.51 \%$ & * & $(0.0547)$ & $0.08 \%$ & (0.9097) \\
\hline & Positive & 8 & $57.72 \%$ & $64.13 \%$ & $57.25 \%$ & $57.62 \%$ & $60.65 \%$ & $55.14 \%$ & $6.69 \%$ & & $(0.1250)$ & $-5.02 \%$ & (0.5469) \\
\hline & & & $(0.6052)$ & $(0.7234)$ & $(0.5312)$ & $(0.4870)$ & $(0.4576)$ & $(0.2697)$ & $(0.5181)$ & & & $61.58 \%$ & \\
\hline Italy & & 14 & $40.12 \%$ & $49.24 \%$ & $29.60 \%$ & $16.67 \%$ & $24.81 \%$ & $38.59 \%$ & $6.58 \%$ & * & $(0.0781)$ & $0.18 \%$ & $(0.8457)$ \\
\hline & Negative & 10 & $56.39 \%$ & $58.59 \%$ & $48.45 \%$ & $24.24 \%$ & $32.64 \%$ & $34.55 \%$ & $6.60 \%$ & & $(0.2500)$ & $-7.27 \%$ & $(0.3750)$ \\
\hline & Positive & 4 & $0.99 \%$ & $8.26 \%$ & $7.41 \%$ & $8.26 \%$ & $24.81 \%$ & $38.59 \%$ & $1.40 \%$ & & $(0.2500)$ & $10.86 \%$ & $(0.2500)$ \\
\hline & & & $(0.1116)$ & $(0.1116)$ & $(0.1360)$ & $(0.3036)$ & $(0.6824)$ & $(0.9436)$ & $(0.8597)$ & & & $6.83 \%$ * & \\
\hline Norway & & 49 & $43.98 \%$ & $36.31 \%$ & $40.12 \%$ & $48.72 \%$ & $53.27 \%$ & $45.06 \%$ & $-0.09 \%$ & & $(0.7925)$ & $0.42 \%$ & $(0.5108)$ \\
\hline & Negative & 34 & $43.50 \%$ & $36.86 \%$ & $42.59 \%$ & $47.33 \%$ & $52.57 \%$ & $42.19 \%$ & $0.46 \%$ & & $(0.6567)$ & $-2.48 \%$ & (0.9096) \\
\hline & Positive & 15 & $48.72 \%$ & $36.31 \%$ & $37.50 \%$ & $49.24 \%$ & $53.27 \%$ & $47.09 \%$ & $-0.64 \%$ & & $(1.0000)$ & $2.91 \%$ & $(0.1937)$ \\
\hline & & & $(0.8976)$ & $(0.6625)$ & (0.3913) & $(0.7284)$ & $(0.8367)$ & $(0.9308)$ & $(0.6993)$ & & & $28.29 \%$ & \\
\hline Spain & & 88 & $32.87 \%$ & $32.89 \%$ & $34.84 \%$ & $41.18 \%$ & $39.02 \%$ & $39.94 \%$ & $5.35 \%$ & $* *$ & $(0.0357)$ & $-0.14 \%$ & $(0.9697)$ \\
\hline & Negative & 57 & $37.68 \%$ & $34.21 \%$ & $38.84 \%$ & $43.50 \%$ & $40.83 \%$ & $40.12 \%$ & $1.62 \%$ & & $(0.1835)$ & $-1.23 \%$ & (0.4956) \\
\hline & Positive & 31 & $23.95 \%$ & $27.79 \%$ & $28.04 \%$ & $37.09 \%$ & $36.71 \%$ & $39.02 \%$ & $7.47 \%$ & * & $(0.0921)$ & $1.45 \%$ & (0.4873) \\
\hline & & & $(0.3112)$ & $(0.4029)$ & $(0.1714)$ & $(0.5409)$ & $(0.8515)$ & $(0.8923)$ & $(0.4516)$ & & & $35.29 \%$ & \\
\hline Sweden & & 82 & $19.36 \%$ & $16.67 \%$ & $16.66 \%$ & $21.26 \%$ & $18.03 \%$ & $22.46 \%$ & $0.87 \%$ & & $(0.2134)$ & $0.05 \%$ & $(0.4164)$ \\
\hline & Negative & 64 & $22.78 \%$ & $20.00 \%$ & $21.88 \%$ & $24.81 \%$ & $26.47 \%$ & $28.57 \%$ & $-0.41 \%$ & & $(0.3176)$ & $2.91 \%$ & $(0.2061)$ \\
\hline & Positive & 18 & $6.54 \%$ & $6.54 \%$ & $9.09 \%$ & $8.66 \%$ & $7.82 \%$ & $5.59 \%$ & $0.99 \%$ & & $(0.3281)$ & $-0.99 \%$ * & $(0.0913)$ \\
\hline & & & $(0.0304)$ ** & $(0.0079)^{* \star *}$ & $(0.0057)^{\star \star \star}$ & $(0.0445)^{\star *}$ & $(0.0743)^{*}$ & $(0.0172)$ ** & $(0.4153)$ & & & $13.18 \%$ & \\
\hline Turkey & & 37 & $21.88 \%$ & $37.11 \%$ & $26.33 \%$ & $20.32 \%$ & $29.58 \%$ & $19.36 \%$ & $8.75 \%$ & & $(0.2121)$ & $0.03 \%$ & $(0.2980)$ \\
\hline & Negative & 4 & $43.18 \%$ & $66.89 \%$ & $57.85 \%$ & $66.14 \%$ & $49.97 \%$ & $41.36 \%$ & $13.47 \%$ & & $(0.5000)$ & $-32.75 \%$ & $(0.2500)$ \\
\hline & Positive & 33 & $17.36 \%$ & $30.68 \%$ & $18.37 \%$ & $17.69 \%$ & $22.48 \%$ & $18.03 \%$ & $8.75 \%$ & & $(0.3484)$ & $0.01 \%$ & (0.8756) \\
\hline & & & $(0.2580)$ & $(0.1747)$ & $(0.0712)$ * & $(0.0246)^{* *}$ & $(0.0465)^{* *}$ & $(0.2803)$ & $(0.7254)$ & & & $3.35 \%$ ** & \\
\hline United Kingdom & & 1,191 & $25.37 \%$ & $30.07 \%$ & $31.03 \%$ & $30.56 \%$ & $30.07 \%$ & $28.57 \%$ & $3.47 \%$ * & & $(<0.0001)$ & $0.02 \%$ & $(0.6729)$ \\
\hline & Negative & 1,011 & $25.93 \%$ & $30.56 \%$ & $31.51 \%$ & $30.56 \%$ & $30.56 \%$ & $29.08 \%$ & $3.73 \%$ * & & $(<0.0001)$ & $0.01 \%$ & $(0.9561)$ \\
\hline & Positive & 180 & $21.88 \%$ & $25.08 \%$ & $26.20 \%$ & $28.57 \%$ & $27.54 \%$ & $26.74 \%$ & $0.85 \%$ & & $(0.1379)$ & $0.04 \%$ & $(0.3290)$ \\
\hline & & & $(0.2722)$ & $(0.0177)$ ** & $(0.1490)$ & $(0.5321)$ & $(0.3062)$ & $(0.3464)$ & $(0.1513)$ & & & $45.69 \%$ & \\
\hline Indonesia & & 165 & $32.43 \%$ & $33.11 \%$ & $42.69 \%$ & $47.92 \%$ & $67.00 \%$ & $77.01 \%$ & $9.06 \%$ * & $\star \star \star \star$ & $(<0.0001)$ & $29.92 \%$ *** & $(<0.0001)$ \\
\hline & Negative & 47 & $28.57 \%$ & $28.06 \%$ & $40.09 \%$ & $45.94 \%$ & $67.21 \%$ & $77.12 \%$ & $13.08 \%$ & ${ }^{*}$ & $(0.0595)$ & $29.18 \%^{* \star \star}$ & $(<0.0001)$ \\
\hline & Positive & 118 & $35.90 \%$ & $35.48 \%$ & $43.82 \%$ & $48.45 \%$ & $66.22 \%$ & $76.99 \%$ & $7.94 \%$ * & & $(<0.0001)$ & $30.11 \%^{\star \star \star}$ & $(<0.0001)$ \\
\hline & & & $(0.1461)$ & $(0.2556)$ & $(0.5428)$ & $(0.9660)$ & $(0.7870)$ & $(0.8270)$ & $(0.4712)$ & & & $94.30 \%$ & \\
\hline Korea & & 713 & $54.75 \%$ & $55.95 \%$ & $56.90 \%$ & $58.68 \%$ & $63.50 \%$ & $55.16 \%$ & $2.97 \%$ * & $\star \star \star \star$ & $(<0.0001)$ & $-0.45 \%$ * & $(0.0610)$ \\
\hline & Negative & 565 & $55.85 \%$ & $56.52 \%$ & $57.98 \%$ & $60.32 \%$ & $64.54 \%$ & $56.14 \%$ & $2.93 \%$ * & $\star \star \star \star$ & $(<0.0001)$ & $-0.60 \%$ * & $(0.0531)$ \\
\hline & Positive & 148 & $48.98 \%$ & $52.60 \%$ & $47.92 \%$ & $50.25 \%$ & $57.63 \%$ & $51.10 \%$ & $2.97 \%$ * & & $(0.0045)$ & $-0.12 \%$ & (0.6724) \\
\hline & & & $(0.0017)^{\star \star \star}$ & $(0.0093)^{* * *}$ & $(0.0002)^{\star \star \star \star}$ & $(0.0010)^{* \star \star}$ & $(0.0013)^{\star \star \star \star}$ & 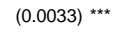 & $(0.9555)$ & & & $70.77 \%$ & \\
\hline Malaysia & & 367 & $20.00 \%$ & $22.48 \%$ & $23.66 \%$ & $29.58 \%$ & $34.21 \%$ & $37.89 \%$ & $2.95 \%$ * & 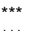 & $(<0.0001)$ & $4.22 \%$ *** & $(<0.0001)$ \\
\hline & Negative & 165 & $16.67 \%$ & $20.00 \%$ & $19.33 \%$ & $28.06 \%$ & $31.27 \%$ & $36.31 \%$ & $2.08 \%$ * & $\star \star \star \star$ & $(0.0003)$ & 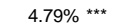 & $(<0.0001)$ \\
\hline & Positive & 202 & $24.24 \%$ & $26.47 \%$ & $28.06 \%$ & $31.26 \%$ & $36.31 \%$ & $40.12 \%$ & $5.09 \%$ * & $\star \star \star \star$ & $(0.0001)$ & $3.90 \% \%^{\star \star \star}$ & $(<0.0001)$ \\
\hline & & & $(0.1923)$ & $(0.2395)$ & $(0.1314)$ & $(0.2334)$ & $(0.1464)$ & (0.4019) & $(0.7839)$ & & & $61.97 \%$ & \\
\hline Philippines & & 153 & $9.09 \%$ & $8.26 \%$ & $12.28 \%$ & $11.50 \%$ & $21.26 \%$ & $21.88 \%$ & $0.03 \%$ & & (0.3399) & $0.01 \%{ }^{\star \star \star}$ & $(<0.0001)$ \\
\hline & Negative & 57 & $8.67 \%$ & $1.96 \%$ & $9.08 \%$ & $1.96 \%$ & $6.54 \%$ & $14.53 \%$ & $0.04 \%$ & & $(0.1973)$ & $0.01 \%^{\star \star \star}$ & $(0.0004)$ \\
\hline & Positive & 96 & $11.07 \%$ & $10.71 \%$ & $15.97 \%$ & $20.26 \%$ & $27.54 \%$ & $26.20 \%$ & $0.02 \%$ & ${ }^{\star \star}$ & $(0.0200)$ & $0.02 \%^{\star \star \star}$ & $(0.0061)$ \\
\hline & & & $(0.9522)$ & $(0.6306)$ & $(0.3261)$ & $(0.0298)$ ** & $(0.0479) * \star$ & $(0.2148)$ & $(0.0065)$ * & 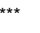 & & $17.45 \%$ & \\
\hline Singapore & & 209 & $21.26 \%$ & $20.00 \%$ & $25.09 \%$ & $28.57 \%$ & $33.33 \%$ & $31.51 \%$ & $2.75 \%$ * & $\star \star \star \star$ & $(0.0000)$ & $0.65 \%$ *** & $(0.0025)$ \\
\hline & Negative & 174 & $21.26 \%$ & $26.47 \%$ & $27.54 \%$ & $29.08 \%$ & $33.33 \%$ & $32.66 \%$ & $3.36 \%$ * & $\star \star \star \star$ & $(0.0000)$ & $0.26 \%$ ** & $(0.0307)$ \\
\hline & Positive & 35 & $21.26 \%$ & $11.50 \%$ & $19.68 \%$ & $23.66 \%$ & $30.34 \%$ & $30.56 \%$ & $0.00 \%$ & & $(0.7238)$ & $4.12 \% \%^{\star \star \star}$ & (0.0079) \\
\hline & & & $(0.9948)$ & $(0.0141)^{* *}$ & $(0.0180)$ ** & $(0.1451)$ & $(0.3873)$ & $(0.6645)$ & $(0.1460)$ & & & $15.37 \%$ & \\
\hline Taiwan & & 320 & $37.89 \%$ & $40.48 \%$ & $47.09 \%$ & $49.50 \%$ & $59.68 \%$ & $51.34 \%$ & $5.58 \%$ * & 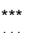 & $(<0.0001)$ & $4.07 \%^{\star \star \star \star}$ & $(<0.0001)$ \\
\hline & Negative & 218 & $37.50 \%$ & $40.48 \%$ & $47.09 \%$ & $48.85 \%$ & $57.08 \%$ & $48.85 \%$ & $4.98 \%$ * & $\star \star \star \star ~$ & $(<0.0001)$ & 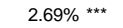 & $(0.0002)$ \\
\hline & Positive & 102 & $40.29 \%$ & $40.12 \%$ & $45.80 \%$ & $50.50 \%$ & $62.62 \%$ & $55.25 \%$ & $6.51 \%$ * & *** & $(0.0000)$ & $5.17 \% \%^{\star \star \star \star}$ & $(0.0001)$ \\
\hline & & & $(0.8267)$ & $(0.4519)$ & (0.5643) & $(0.9322)$ & $(0.3676)$ & $(0.6166)$ & $(0.4685)$ & & & $48.14 \%$ & \\
\hline Thailand & & 154 & $28.31 \%$ & $27.54 \%$ & $26.74 \%$ & $28.57 \%$ & $28.06 \%$ & $29.58 \%$ & $0.93 \%$ & & $(0.4472)$ & $0.41 \%^{* \star}$ & $(0.0356)$ \\
\hline & Negative & 14 & $27.01 \%$ & $23.59 \%$ & $25.37 \%$ & $28.57 \%$ & $24.81 \%$ & $30.31 \%$ & $0.57 \%$ & & $(0.3125)$ & $2.66 \%$ & $(0.3013)$ \\
\hline & Positive & 140 & $28.57 \%$ & $28.06 \%$ & $27.01 \%$ & $28.57 \%$ & $29.08 \%$ & $29.58 \%$ & $1.26 \%$ & & $(0.8021)$ & $0.02 \%$ * & $(0.0734)$ \\
\hline & & & $(0.4174)$ & $(0.2851)$ & (0.8165) & $(0.8373)$ & (0.8943) & $(0.2179)$ & $(0.3278)$ & & & $47.99 \%$ & \\
\hline Brazil & & 15 & $18.51 \%$ & $18.03 \%$ & $22.48 \%$ & $20.64 \%$ & $25.48 \%$ & $32.43 \%$ & $0.07 \%$ & & $(1.0000)$ & $10.12 \%$ & $(0.0005)$ \\
\hline & Negative & 5 & $11.50 \%$ & $8.26 \%$ & $23.08 \%$ & $22.62 \%$ & $21.88 \%$ & $26.47 \%$ & $0.78 \%$ & & $(1.0000)$ & $8.43 \%$ & $(0.1250)$ \\
\hline & Positive & 10 & $22.48 \%$ & $20.56 \%$ & $20.26 \%$ & $20.64 \%$ & $29.08 \%$ & $33.96 \%$ & $-1.68 \%$ & & $(1.0000)$ & $10.12 \%^{\star \star \star}$ & $(0.0078)$ \\
\hline & & & $(0.3827)$ & (0.5613) & (0.6098) & $(0.8170)$ & $(1.0000)$ & $(0.6682)$ & $(0.8026)$ & & & $79.89 \%$ & \\
\hline Mexico & & 29 & $31.51 \%$ & $31.97 \%$ & $36.71 \%$ & $37.07 \%$ & $45.06 \%$ & $43.18 \%$ & $9.43 \%$ & ** & $(0.0210)$ & $8.50 \%$ *** & $(<0.0001)$ \\
\hline & Negative & 24 & $29.78 \%$ & $31.51 \%$ & $35.69 \%$ & $34.64 \%$ & $43.18 \%$ & $38.99 \%$ & $8.87 \%$ & ** & $(0.0322)$ & $8.07 \%$ *** & $(<0.0001)$ \\
\hline & Positive & 5 & $42.86 \%$ & $45.71 \%$ & $47.64 \%$ & $50.00 \%$ & $65.19 \%$ & $68.05 \%$ & $11.69 \%$ & & $(1.0000)$ & $17.43 \%$ * & $(0.0625)$ \\
\hline & & & $(0.5040)$ & $(0.3722)$ & (0.2825) & $(0.1400)$ & $(0.1942)$ & (0.1259) & $(0.3848)$ & & & $3.65 \%$ ** & \\
\hline Venezuela & Positive & 7 & $27.76 \%$ & $31.03 \%$ & $22.18 \%$ & $26.17 \%$ & $29.29 \%$ & $21.88 \%$ & $-4.24 \%$ & & $(1.0000)$ & $-3.91 \%$ & $(0.2969)$ \\
\hline
\end{tabular}

Table IV b. Debt to Value Ratio at the country level.

This table displays the median Debt to Value Ratio for a sample of firms in countries that have suffered a currency crises in the period 1985-2000. 'Europe' includes firms from Finland, Italy, Norway, Spain, Sweden, Turkey and the United Kingdom. 'Asia' includes firms from Indonesia, Korea, Malaysia, Philippines, Singapore, Taiwan and Thailand. 'Latin America' includes firms from Brazil, Mexico, and Venezuela. Firms are divided into two groups base on their exchange rate beta, which is calculated as follows: for every country in our sample, we estimate the regression , where is the corresponding market return, and is the change in the exchange rate for the same period. We estimate the

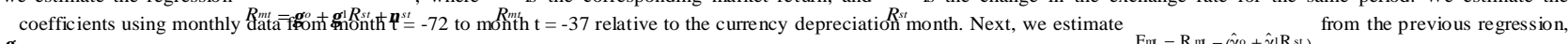

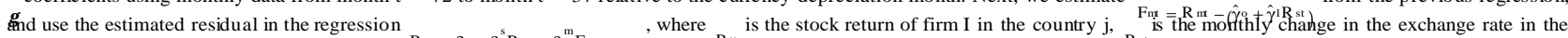

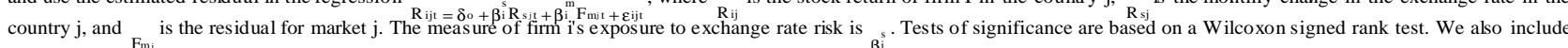
the p-value for a test of equal medians between negative and positive exchange rate beta firms. This test is based on a two-tailed Wilcoxon rank test. 


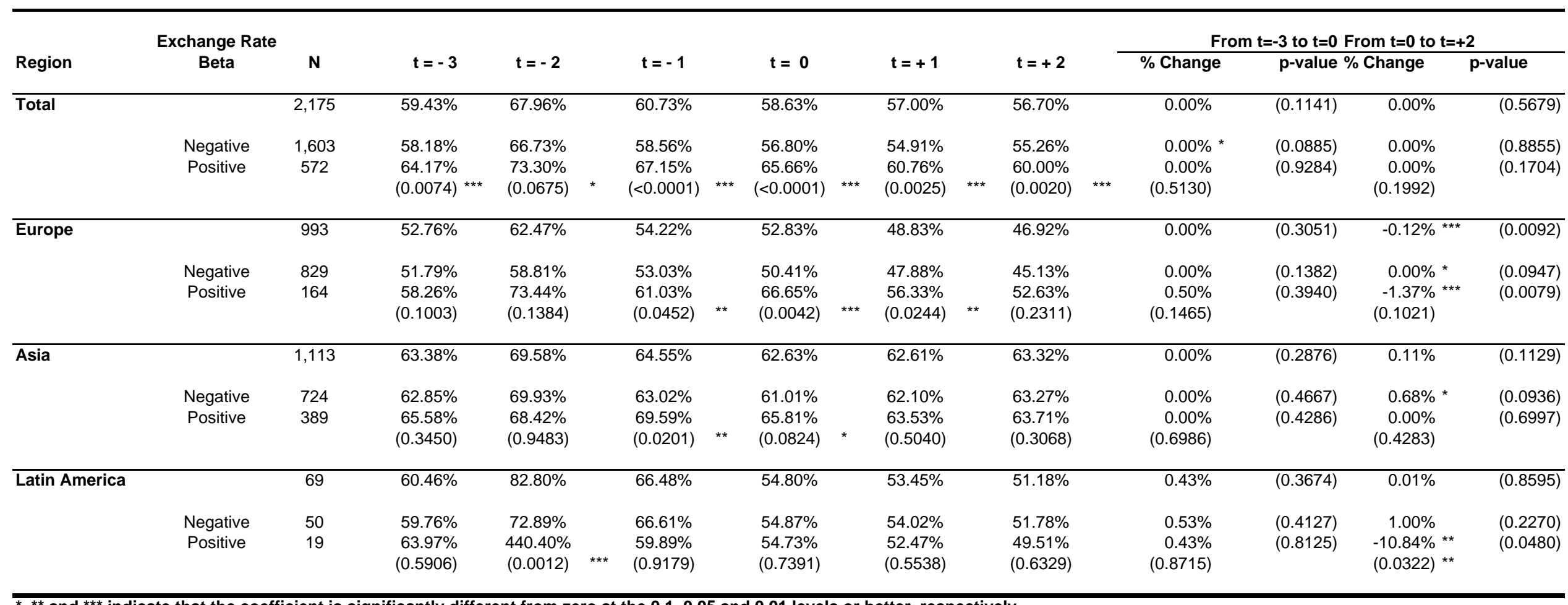

${ }^{\star \star}$ and ${ }^{\star \star \star}$ indicate that the coefficient is significantly different from zero at the $0.1,0.05$ and 0.01 levels or better, respectively.

Table V. Percentage of Short-Term Debt on Total Debt.

This table displays the ratio of Short-Term Debt to Total Debt for a sample of firms in countries that have suffered a currency crises in the period 1985-2000. 'Europe' includes firms from Finland, Italy, Norway, Spain, Sweden, Turkey and the United Kingdom. 'Asia' includes firms from Indonesia, Korea, Malaysia, Philippines, Singapore, Taiwan and Thailand. 'Latin America' includes firms from Brazil, Mexico, and Venezuela. Firms are divided into two groups base on their exchange rate beta, which is calculated as follows: for every country in our sample, we estimate the regression $R_{m t}=\gamma_{o}+\gamma_{1} R_{s t}+v_{s t}$, where $R_{m t}$ is the corresponding market return, and $R_{s t}$ is the change in the exchange rate for the same period. We estimate the $\gamma$ coefficients using monthly data from month $\mathrm{t}=-72$ to month $\mathrm{t}=-37$ relative to the currency depreciation month. Next, we estimate $F_{m t}=R_{m t}-\left(\hat{\gamma}_{o}+\hat{\gamma}_{1} R_{s t}\right)$ from the previous regression, and use the estimated residual in the regression $R_{i j t}=\delta_{o}+\beta_{i}^{s} R_{s_{j} t}+\beta_{i}^{m} F_{m_{j} t}+\varepsilon_{i j t}$, where $R_{i j}$ is the stock return of firm I in the country j, $R_{s j}$ is the monthly change in the exchange rate in the country $j$, and $F_{m_{j}}$ is the residual for market $\mathrm{j}$. The measure of firm i's exposure to exchange rate risk is $\beta_{\mathrm{i}}^{\mathrm{s}}$. Stock returns, Exchange rates, Market Returns and accounting variables are from Datastream. Tests of significance are based on a Wilcoxon signed rank test. We also include the p-value for a test of equal medians between negative and positive exchange rate beta firms. This test is based on a two-tailed Wilcoxon rank test. 


\begin{tabular}{|c|c|c|c|c|c|c|c|c|c|c|c|c|c|c|c|c|c|c|}
\hline \multirow[b]{2}{*}{ Region } & \multirow{2}{*}{$\begin{array}{c}\text { Exchange Rate } \\
\text { Beta }\end{array}$} & \multirow[b]{2}{*}{$\mathbf{N}$} & \multirow[b]{2}{*}{$t=-3$} & \multirow{2}{*}{\multicolumn{2}{|c|}{$t=-2$}} & \multirow{2}{*}{\multicolumn{2}{|c|}{$t=-1$}} & \multirow{2}{*}{\multicolumn{2}{|c|}{$t=0$}} & \multirow{2}{*}{\multicolumn{2}{|c|}{$t=+1$}} & \multirow{2}{*}{\multicolumn{2}{|c|}{$t=+2$}} & & \multicolumn{2}{|c|}{ From $t=-3$ to $t=0$} & \multicolumn{2}{|c|}{ From $\mathrm{t}=0$ to $\mathrm{t}=+2$} \\
\hline & & & & & & & & & & & & & & & \% Change & $p$-value & \% Change & $\overline{p \text {-value }}$ \\
\hline \multirow[t]{4}{*}{$\begin{array}{l}\text { Total } \\
\end{array}$} & & 2,018 & $10.23 \%$ & & $10.09 \%$ & & $9.38 \%$ & & $8.72 \%$ & & $8.20 \%$ & & $8.79 \%$ & & $-13.57 \% \%^{* \star *}$ & $(<0.0001)$ & $0.37 \%$ *** & $\overline{(<0.0001)}$ \\
\hline & Negative & 1,508 & $9.95 \%$ & & $9.73 \%$ & & $8.91 \%$ & & $8.18 \%$ & & $7.79 \%$ & & $8.31 \%$ & & $-15.08 \%$ *** & $(<0.0001)$ & $0.01 \%{ }^{* * *}$ & $(<0.0001)$ \\
\hline & Positive & 510 & $12.17 \%$ & & $11.60 \%$ & & $11.15 \%$ & & $10.75 \%$ & & $9.49 \%$ & & $10.51 \%$ & & $-8.18 \%$ *** & $(0.0070)$ & $0.99 \% \%^{* \star \star}$ & $(0.0036)$ \\
\hline & & & $(<0.0001)$ & $* * *$ & $(<0.0001)$ & $* * *$ & $(<0.0001)$ & $* \star *$ & $(<0.0001)$ & $* * *$ & $(<0.0001)$ & $* * *$ & $(<0.0001)$ & 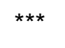 & $(0.0025)^{* * *}$ & & $(0.8617)$ & \\
\hline \multirow[t]{4}{*}{ Europe } & & 1,022 & $10.60 \%$ & & $10.29 \%$ & & $9.22 \%$ & & $8.38 \%$ & & $7.98 \%$ & & $8.16 \%$ & & $-20.78 \%{ }^{* \star *}$ & $(<0.0001)$ & $-4.52 \%$ & $\overline{(0.4039)}$ \\
\hline & Negative & 853 & $10.58 \%$ & & $10.23 \%$ & & $9.04 \%$ & & $8.21 \%$ & & $7.86 \%$ & & $8.07 \%$ & & $-21.48 \%$ *** & $(<0.0001)$ & $-4.93 \%$ & $(0.4398)$ \\
\hline & Positive & 169 & $11.51 \%$ & & $10.66 \%$ & & $9.71 \%$ & & $9.17 \%$ & & $8.64 \%$ & & $8.86 \%$ & & $-11.71 \%$ ** & $(0.0152)$ & $-2.76 \%$ & $(0.7518)$ \\
\hline & & & $(0.6542)$ & & $(0.5665)$ & & $(0.1528)$ & & $(0.0424)$ & $* * *$ & $(0.0750)$ & * & $(0.0300)$ & $* *$ & $(0.0179) \quad$ ** & & $(0.9189)$ & \\
\hline \multirow[t]{4}{*}{ Asia } & & 908 & $9.61 \%$ & & $9.86 \%$ & & $9.67 \%$ & & $9.06 \%$ & & $8.54 \%$ & & $10.31 \%$ & & $-8.68 \% \%^{* * *}$ & $(0.0003)$ & $11.31 \%^{* \star *}$ & $\overline{(<0.0001)}$ \\
\hline & Negative & 586 & $8.97 \%$ & & $8.87 \%$ & & $8.83 \%$ & & $8.05 \%$ & & $7.71 \%$ & & $9.24 \%$ & & $-9.74 \%{ }^{* \star *}$ & $(0.0012)$ & $16.56 \%{ }^{* \star \star}$ & $(<0.0001)$ \\
\hline & Positive & 322 & $12.34 \%$ & & $12.40 \%$ & & $11.73 \%$ & & $11.56 \%$ & & $10.30 \%$ & & $11.53 \%$ & & $-6.40 \% \quad *$ & $(0.0941)$ & $6.03 \% * * *$ & $(0.0009)$ \\
\hline & & & $(<0.0001)$ & $* \star *$ & $(<0.0001)$ & $* * *$ & $(<0.0001)$ & $* * *$ & $(<0.0001)$ & $* * *$ & $(<0.0001)$ & $* * *$ & $(<0.0001)$ & $* * *$ & $(0.5924)$ & & $(0.1905)$ & \\
\hline \multirow[t]{4}{*}{ Latin America } & & 88 & $10.02 \%$ & & $10.12 \%$ & & $9.28 \%$ & & $8.87 \%$ & & $7.62 \%$ & & $8.38 \%$ & & $-8.71 \%$ & $(0.4574)$ & $-3.78 \%$ & $\overline{(0.1213)}$ \\
\hline & Negative & 69 & $9.96 \%$ & & $10.13 \%$ & & $9.33 \%$ & & $8.44 \%$ & & $7.62 \%$ & & $8.02 \%$ & & $-11.79 \%$ & $(0.2910)$ & $-8.19 \%$ & $(0.5248)$ \\
\hline & Positive & 19 & $12.96 \%$ & & $9.07 \%$ & & $9.22 \%$ & & $9.76 \%$ & & $7.84 \%$ & & $10.08 \%$ & & $-1.41 \%$ & $(0.8203)$ & $41.59 \%$ ** & $(0.0343)$ \\
\hline & & & $(0.1884)$ & & (0.8432) & & $(0.8765)$ & & $(0.5778)$ & & $(0.3535)$ & & $(0.3277)$ & & $(0.4517)$ & & $(0.1533)$ & \\
\hline
\end{tabular}

${ }^{*},{ }^{* *}$ and ${ }^{* * *}$ indicate that the coefficient is significantly different from zero at the $0.1,0.05$ and 0.01 levels or better, respectively.

\section{Table VI. EBIT to Revenues Ratio.}

This table displays the median EBIT to Revenues Ratio for a sample of firms in countries that have suffered a currency crises in the period 1985-2000. 'Europe' includes firms from Finland, Italy, Norway, Spain, Sweden, Turkey and the United Kingdom. 'Asia' includes firms from Indonesia, Korea, Malaysia, Philippines, Singapore, Taiwan and Thailand. 'Latin America' includes firms from Brazil, Mexico, and Venezuela. Firms are divided into two groups base on their exchange rate beta, which is calculated as follows: for every country in our sample, we estimate the regression $R_{m t}=\gamma_{o}+\gamma_{1} R_{s t}+\mathrm{v}_{s t}$, where $R_{m t}$ is the corresponding market return, and $R_{s t}$ is the change in the exchange rate for the same period. We estimate the $\gamma$ coefficients using monthly data from month $\mathrm{t}=-72$ to month $\mathrm{t}=-37$ relative to the currency depreciation month. Next, we estimate $F_{n t}=R_{n t}-\left(\hat{\gamma}_{o}+\hat{\gamma}_{1} R_{s t}\right)$ from the previous regression, and use the estimated residual in the regression $R_{i j t}=\delta_{o}+\beta_{i}^{s} R_{s_{j} t}+\beta_{i}^{m} F_{m_{j} t}+\varepsilon_{i j t}$, where $R_{i j}$ is the stock return of firm $I$ in the country $\mathrm{j}, \mathrm{R}_{\mathrm{sj}}$ is the monthly change in the exchange rate in the country $\mathrm{j}$, and $\mathrm{F}_{\mathrm{m}_{\mathrm{j}}}$ is the residual for market $\mathrm{j}$. The measure of firm i's exposure to exchange rate risk is $\beta_{\mathrm{i}}^{\mathrm{s}}$. Tests of significance are based on a Wilcoxon signed rank test. We also include the p-value for a test of equal medians between negative and positive exchange rate beta firms. This test is based on a two-tailed Wilcoxon rank test. 


\begin{tabular}{|c|c|c|c|c|c|c|c|c|c|c|c|c|c|c|c|c|c|}
\hline \multirow[b]{2}{*}{ Region } & \multirow{2}{*}{$\begin{array}{c}\text { Exchange Rate } \\
\text { Beta }\end{array}$} & \multirow[b]{2}{*}{$\mathbf{N}$} & \multirow[b]{2}{*}{$t=-3$} & \multirow[b]{2}{*}{$t=-2$} & \multirow{2}{*}{\multicolumn{2}{|c|}{$t=-1$}} & \multirow{2}{*}{\multicolumn{2}{|c|}{$t=0$}} & \multirow{2}{*}{\multicolumn{2}{|c|}{$t=+1$}} & \multirow{2}{*}{\multicolumn{2}{|c|}{$t=+2$}} & & \multicolumn{2}{|c|}{ From $t=-3$ to $t=0$} & \multicolumn{2}{|c|}{ From $t=0$ to $t=+2$} \\
\hline & & & & & & & & & & & & & & \% Change & $p$-value & \% Change & $\overline{p-v a l u e}$ \\
\hline \multirow[t]{3}{*}{ Total } & & 3,696 & $9.80 \%$ & $9.31 \%$ & & $8.54 \%$ & & $7.58 \%$ & & $6.56 \%$ & & $6.68 \%$ & & $-27.19 \%^{* * *}$ & $(<0.0001)$ & $-19.59 \%^{* * *}$ & $\overline{(<0.0001)}$ \\
\hline & Negative & 2,626 & $10.27 \%$ & $9.61 \%$ & & $8.68 \%$ & & $7.74 \%$ & & $6.77 \%$ & & $7.15 \%$ & & $-28.06 \% * * *$ & $(<0.0001)$ & $-16.25 \%$ *** & $(<0.0001)$ \\
\hline & Positive & 1,070 & $\begin{array}{c}7.83 \% \\
(<0.0001)^{* * *}\end{array}$ & $\begin{array}{c}8.54 \% \\
(0.0003)\end{array}$ & $* * *$ & $\begin{array}{c}8.24 \% \\
(0.2323)\end{array}$ & & $\begin{array}{c}7.09 \% \\
(0.0595)\end{array}$ & * & $\begin{array}{c}5.92 \% \\
(0.1323)\end{array}$ & & $\begin{array}{c}5.37 \% \\
(0.1323)\end{array}$ & $* * *$ & $\begin{array}{l}-23.69 \% \text { *** } \\
(0.0885) *\end{array}$ & $(<0.0001)$ & $\begin{array}{l}-32.38 \% \text { *** } \\
(0.0002) * * *\end{array}$ & $(<0.0001)$ \\
\hline \multirow[t]{3}{*}{ Europe } & & 1,393 & $19.64 \%$ & $17.61 \%$ & & $14.33 \%$ & & $12.02 \%$ & & $11.39 \%$ & & $11.90 \%$ & & $-33.26 \%^{\star \star *}$ & $(<0.0001)$ & $-7.80 \%{ }^{\star * *}$ & $\overline{(<0.0001)}$ \\
\hline & Negative & 1,131 & $19.89 \%$ & $17.77 \%$ & & $14.51 \%$ & & $12.00 \%$ & & $11.25 \%$ & & $11.91 \%$ & & $-34.30 \%$ *** & $(<0.0001)$ & $-6.74 \%$ *** & $(<0.0001)$ \\
\hline & Positive & 262 & $\begin{array}{r}18.04 \% \\
(0.7453)\end{array}$ & $\begin{array}{l}16.64 \% \\
(0.7472)\end{array}$ & & $\begin{array}{l}13.92 \% \\
(0.3705)\end{array}$ & & $\begin{array}{l}12.16 \% \\
(0.6772)\end{array}$ & & $\begin{array}{l}11.91 \% \\
(0.1228)\end{array}$ & & $\begin{array}{l}11.63 \% \\
(0.1323)\end{array}$ & & $\begin{array}{l}-32.53 \%{ }^{* * *} \\
(0.4934)\end{array}$ & $(<0.0001)$ & $\begin{array}{l}-10.72 \%{ }^{* * *} \\
(0.2736)\end{array}$ & $(0.0042)$ \\
\hline \multirow[t]{3}{*}{ Asia } & & 2,217 & $5.99 \%$ & $6.68 \%$ & & $6.53 \%$ & & $6.01 \%$ & & $4.79 \%$ & & $4.00 \%$ & & $-20.38 \%^{* * *}$ & $(<0.0001)$ & $-34.91 \%{ }^{* * *}$ & $(<0.0001)$ \\
\hline & Negative & 1,437 & $6.06 \%$ & $6.62 \%$ & & $6.29 \%$ & & $5.88 \%$ & & $4.66 \%$ & & $4.11 \%$ & & $-20.88 \%$ *** & $(<0.0001)$ & $-30.18 \%$ *** & $(<0.0001)$ \\
\hline & Positive & 780 & $\begin{array}{r}5.70 \% \\
(0.8772)\end{array}$ & $\begin{array}{c}6.89 \% \\
(0.0692)\end{array}$ & * & $\begin{array}{c}6.87 \% \\
(0.0053)\end{array}$ & $* * *$ & $\begin{array}{c}6.23 \% \\
(0.0344)\end{array}$ & ** & $\begin{array}{c}4.94 \% \\
(0.0345)\end{array}$ & ** & $\begin{array}{c}3.79 \% \\
(0.1323)\end{array}$ & & $\begin{array}{l}-19.44 \% \%^{* * *} \\
(0.8837)\end{array}$ & $(<0.0001)$ & $\begin{array}{l}-41.42 \% \text { *** } \\
(0.0364)^{* *}\end{array}$ & $(<0.0001)$ \\
\hline \multirow[t]{3}{*}{ Latin America } & & 86 & $17.32 \%$ & $15.07 \%$ & & $13.63 \%$ & & $10.63 \%$ & & $7.15 \%$ & & $11.08 \%$ & & $-35.48 \%^{* * *}$ & $(0.0002)$ & $-3.60 \%$ & $\overline{(0.9961)}$ \\
\hline & Negative & 58 & $17.32 \%$ & $15.07 \%$ & & $12.24 \%$ & & $10.85 \%$ & & $7.59 \%$ & & $11.08 \%$ & & $-35.48 \%$ *** & $(0.0001)$ & $-8.30 \%$ & $(0.3831)$ \\
\hline & Positive & 28 & $\begin{array}{r}17.24 \% \\
(0.7898)\end{array}$ & $\begin{array}{l}19.33 \% \\
(0.6064)\end{array}$ & & $\begin{array}{l}17.44 \% \\
(0.0488)\end{array}$ & ** & $\begin{array}{c}9.72 \% \\
(0.9118)\end{array}$ & & $\begin{array}{c}4.12 \% \\
(0.8443)\end{array}$ & & $\begin{array}{l}10.61 \% \\
(0.1323)\end{array}$ & & $\begin{array}{l}-17.71 \% \\
(0.3943)\end{array}$ & $(0.4961)$ & $\begin{array}{r}17.36 \% \\
(0.1114)\end{array}$ & (0.1867) \\
\hline
\end{tabular}

\section{Table VII. Return On Capital Employed.}

This table displays the median Return on Capital Employed (ROCE) for a sample of firms in countries that have suffered a currency crises in the period 1985-2000. 'Europe' includes firms from Finland, Italy, Norway, Spain, Sweden, Turkey and the United Kingdom. 'Asia' includes firms from Indonesia, Korea, Malaysia, Philippines, Singapore, Taiwan and Thailand. 'Latin America' includes firms from Brazil, Mexico, and Venezuela. Firms are divided into two groups base on their exchange rate beta, which is calculated as follows: for every country in our sample, we estimate the regression $R_{m t}=\gamma_{o}+\gamma_{1} R_{s t}+v_{s t}$, where $R_{m t}$ is the corresponding market return, and $R_{s t}$ is the change in the exchange rate for the same period. We estimate the $\gamma$ coefficients using monthly data from month $\mathrm{t}=-72$ to month $\mathrm{t}=-37$ relative to the currency depreciation month. Next, we estimate $F_{m t}=R_{m t}-\left(\hat{\gamma}_{o}+\hat{\gamma}_{1} R_{s t}\right)$ from the previous regression, and use the estimated residual in the regression $R_{i j t}=\delta_{o}+\beta_{i}^{s} R_{s_{j} t}+\beta_{i}^{m} F_{m_{j} t}+\varepsilon_{i j t}$, where $R_{i j}$ is the stock return of firm $I$ in the country $j, R_{s j}$ is the monthly change in the exchange rate in the country $j$, and $F_{m_{j}}$ is the residual for market $j$. The measure of firm i's exposure to exchange rate risk is $\beta_{i}^{s}$. Stock returns, Exchange rates, Market Returns and accounting variables are from Datastream. Tests of significance are based on a Wilcoxon signed rank test. We also include the p-value for a test of equal medians between negative and positive exchange rate beta firms. This test is based on a two-tailed Wilcoxon rank test. 


\begin{tabular}{|c|c|c|c|c|c|c|c|c|c|c|c|c|c|c|c|c|c|}
\hline \multirow[b]{2}{*}{ Region } & \multirow{2}{*}{$\begin{array}{c}\text { Exchange Rate } \\
\text { Beta }\end{array}$} & \multirow[b]{2}{*}{$\mathbf{N}$} & \multirow[b]{2}{*}{$t=-3$} & \multirow{2}{*}{\multicolumn{2}{|c|}{$t=-2$}} & \multirow[b]{2}{*}{$t=-1$} & \multirow{2}{*}{\multicolumn{2}{|c|}{$t=0$}} & \multirow{2}{*}{\multicolumn{2}{|c|}{$t=+1$}} & \multirow{2}{*}{\multicolumn{2}{|c|}{$t=+2$}} & & \multicolumn{2}{|c|}{ From $t=-3$ to $t=0$} & \multicolumn{2}{|c|}{ From $t=0$ to $t=+2$} \\
\hline & & & & & & & & & & & & & & $\%$ Change & $p$-value & \% Change & p-value \\
\hline \multirow[t]{4}{*}{ Total } & & 2,907 & 1.38 & & 1.38 & 1.35 & & 1.33 & & 1.25 & & 1.27 & & $-4.57 \%^{* * *}$ & $(0.0004)$ & $-3.43 \%{ }^{* * *}$ & $\overline{(<0.0001)}$ \\
\hline & Negative & 2,025 & 1.40 & & 1.38 & 1.33 & & 1.32 & & 1.26 & & 1.27 & & $-4.80 \%{ }^{* \star *}$ & $(0.0005)$ & $-2.12 \%{ }^{* * *}$ & $(0.0020)$ \\
\hline & Positive & 882 & 1.32 & & 1.38 & 1.39 & & 1.36 & & 1.23 & & 1.25 & & $-3.85 \%$ & $(0.2655)$ & $-7.91 \%$ *** & $(0.0019)$ \\
\hline & & & $(0.0332)$ & $* *$ & $(0.6448)$ & $(0.0790)$ & * & $(0.0567)$ & * & $(0.7461)$ & & $(0.2969)$ & & $(0.8773)$ & & $(0.0431) * *$ & \\
\hline \multirow[t]{4}{*}{ Europe } & & 1,254 & 1.39 & & 1.34 & 1.32 & & 1.33 & & 1.34 & & 1.37 & & $-2.73 \%$ & $(0.1450)$ & $1.37 \%^{* * \star}$ & $\begin{array}{l}(0.0008) \\
\end{array}$ \\
\hline & Negative & 1,019 & 1.39 & & 1.34 & 1.32 & & 1.34 & & 1.35 & & 1.37 & & $-1.96 \%$ & $(0.7296)$ & $0.95 \%$ ** & $(0.0406)$ \\
\hline & Positive & 235 & 1.43 & & 1.36 & 1.33 & & 1.29 & & 1.32 & & 1.41 & & $-7.32 \%{ }^{* * \star}$ & $(0.0036)$ & $3.94 \%$ *** & $(0.0006)$ \\
\hline & & & $(0.6215)$ & & $(0.7654)$ & $(0.7256)$ & & $(0.2417)$ & & $(0.5769)$ & & $(0.5310)$ & & $(0.0077)^{* * *}$ & & $(0.0213) * *$ & \\
\hline \multirow[t]{4}{*}{$\overline{\text { Asia }}$} & & 1,538 & 1.34 & & 1.41 & 1.37 & & 1.32 & & 1.15 & & 1.12 & & $-6.77 \%^{* * *}$ & $(0.0019)$ & $-13.42 \%$ *** & $\overline{(<0.0001)}$ \\
\hline & Negative & 928 & 1.38 & & 1.42 & 1.35 & & 1.29 & & 1.13 & & 1.12 & & $-9.67 \%^{* * *}$ & $(<0.0001)$ & $-10.50 \%{ }^{\star \star \star}$ & $(<0.0001)$ \\
\hline & Positive & 610 & 1.28 & & 1.36 & 1.40 & & 1.42 & & 1.19 & & 1.12 & & $-2.41 \%$ & $(0.7143)$ & $-17.79 \% \%^{\star * *}$ & $(<0.0001)$ \\
\hline & & & $(0.0492)$ & $* *$ & $(0.8304)$ & $(0.1459)$ & & $(0.0043)$ & $\star \star \star *$ & (0.0355) & ** & $(0.8826)$ & & $(0.0250) * *$ & & (0.1025) & \\
\hline \multirow{3}{*}{ Latin America } & Negative & 78 & 1.66 & & 1.65 & 1.49 & & 1.56 & & 1.35 & & 1.44 & & $-5.56 \%$ & $(0.2613)$ & $-6.74 \%$ ** & $(0.0127)$ \\
\hline & Positive & 37 & 1.36 & & 1.61 & 1.72 & & 1.49 & & 1.43 & & 1.69 & & $4.29 \%$ & $(0.5678)$ & $5.56 \%$ & $(0.6695)$ \\
\hline & & & $(0.0567)$ & * & $(0.9314)$ & $(0.0688)$ & * & $(0.4607)$ & & (0.1031) & & $(0.0966)$ & * & (0.2901) & & $(0.0903)$ * & \\
\hline
\end{tabular}

${ }^{*}{ }^{* \star}$ and ${ }^{\star \star \star}$ indicate that the coefficient is significantly different from zero at the $0.1,0.05$ and 0.01 levels or better, respectively.

\section{Table VIII. Current Ratio.}

This table displays the median Current Assets to Current Liabilities Ratio for a sample of firms in countries that have suffered a currency crises in the period 1985-2000. 'Europe' includes firms from Finland, Italy, Norway, Spain, Sweden, Turkey and the United Kingdom. 'Asia' includes firms from Indonesia, Korea, Malaysia, Philippines, Singapore, Taiwan and Thailand. 'Latin America' includes firms from Brazil, Mexico, and Venezuela. Firms are divided into two groups base on their exchange rate beta, which is calculated as follows: for every country in our sample, we estimate the regression $R_{m t}=\gamma_{o}+\gamma_{1} R_{s t}+v_{s t}$, where $R_{m t}$ is the corresponding market return, and $R_{s t}$ is the change in the exchange rate for the same period. We estimate the $\gamma$ coefficients using monthly data from month $\mathrm{t}=-72$ to month $\mathrm{t}=-37$ relative to the currency depreciation month. Next, we estimate $F_{m t}=R_{m t}-\left(\hat{\gamma}_{o}+\hat{\gamma}_{1} R_{s t}\right)$ from the previous regression, and use the estimated residual in the regression $R_{i j t}=\delta_{o}+\beta_{i}^{s} R_{s_{j} t}+\beta_{i}^{m} F_{m i t}+\varepsilon_{i j t}$, where $R_{i j}$ is the stock return of firm I in the country $j, R_{s j}$ is the monthly change in the exchange rate in the country $j$, and $F_{m_{j}}$ is the residual for market $j$. The measure of firm i's exposure to exchange rate risk is $\beta_{\mathrm{i}}^{\mathrm{s}}$. Stock returns, Exchange rates, Market Returns and accounting variables are from Datastream. Tests of significance are based on a Wilcoxon signed rank test. We also include the p-value for a test of equal medians between negative and positive exchange rate beta firms. This test is based on a two-tailed Wilcoxon rank test. 


\begin{tabular}{|c|c|c|c|c|c|c|c|c|c|c|c|c|c|c|c|c|c|c|}
\hline \multirow[b]{2}{*}{ Region } & \multirow{2}{*}{$\begin{array}{c}\text { Exchange Rate } \\
\text { Beta }\end{array}$} & \multirow[b]{2}{*}{$\mathbf{N}$} & \multirow[b]{2}{*}{$t=-3$} & \multirow{2}{*}{\multicolumn{2}{|c|}{$t=-2$}} & \multirow{2}{*}{\multicolumn{2}{|c|}{$t=-1$}} & \multirow{2}{*}{\multicolumn{2}{|c|}{$t=0$}} & \multirow{2}{*}{\multicolumn{2}{|c|}{$t=+1$}} & \multirow{2}{*}{\multicolumn{2}{|c|}{$t=+2$}} & & \multicolumn{2}{|c|}{ From $t=-3$ to $t=0$} & \multicolumn{2}{|c|}{ From $t=0$ to $t=+2$} \\
\hline & & & & & & & & & & & & & & & \% Change & p-value & \% Change & p-value \\
\hline \multirow[t]{4}{*}{ Total } & & 1,663 & 5.11 & & 3.79 & & 3.07 & & 2.84 & & 2.98 & & 3.79 & & $-35.58 \%^{\star \star \star}$ & $(<0.0001)$ & $18.44 \%^{* \star *}$ & $(<0.0001)$ \\
\hline & Negative & 1,282 & 5.24 & & 3.69 & & 2.83 & & 2.54 & & 2.86 & & 3.73 & & $-37.21 \% * * *$ & $(<0.0001)$ & $21.34 \% \%^{* * *}$ & $(<0.0001)$ \\
\hline & Positive & 381 & 4.49 & & 3.95 & & 3.96 & & 3.70 & & 3.38 & & 3.90 & & $-28.77 \%$ *** & $(<0.0001)$ & $6.44 \%$ *** & $(0.0001)$ \\
\hline & & & $(0.9228)$ & & $(0.0147)$ & $* *$ & $(<0.0001)$ & $* * *$ & $(<0.0001)$ & $* * *$ & $(0.0011)$ & $* * *$ & $(0.1587)$ & & $(0.0422) * *$ & & $(0.0010)^{* \star \star}$ & \\
\hline \multirow[t]{4}{*}{ Europe } & & 1,117 & 7.52 & & 5.28 & & 4.26 & & 4.06 & & 4.27 & & 5.33 & & $-45.79 \%^{* * *}$ & $(<0.0001)$ & $33.46 \% \%^{* * *}$ & $(<0.0001)$ \\
\hline & Negative & 936 & 7.58 & & 5.29 & & 4.21 & & 4.05 & & 4.28 & & 5.47 & & $-46.74 \%$ *** & $(<0.0001)$ & $32.33 \%$ *** & $(<0.0001)$ \\
\hline & Positive & 181 & 6.89 & & 5.02 & & 4.53 & & 4.34 & & 4.05 & & 4.96 & & $-41.60 \%$ *** & $(0.0038)$ & $37.81 \%$ *** & $(<0.0001)$ \\
\hline & & & $(0.6189)$ & & $(0.8635)$ & & $(0.2404)$ & & $(0.6763)$ & & $(0.2555)$ & & $(0.3102)$ & & $(0.2047)$ & & $(0.5246)$ & \\
\hline \multirow[t]{4}{*}{ Asia } & & 415 & 1.21 & & 1.35 & & 1.33 & & 1.27 & & 1.29 & & 1.27 & & $-14.38 \% \%^{* * *}$ & $(<0.0001)$ & $-9.10 \%$ & $(0.4628)$ \\
\hline & Negative & 270 & 1.15 & & 1.17 & & 1.07 & & 1.00 & & 1.02 & & 1.02 & & $-14.36 \%$ *** & $(<0.0001)$ & $-4.82 \%$ & $(0.4779)$ \\
\hline & Positive & 145 & 2.16 & & 3.31 & & 3.67 & & 3.35 & & 2.96 & & 2.70 & & $-16.37 \%$ & $(0.4311)$ & $-16.47 \%$ ** & (0.0189) \\
\hline & & & $(<0.0001)$ & $* * *$ & $(<0.0001)$ & $* * *$ & $(<0.0001)$ & $* * *$ & $(<0.0001)$ & $* * *$ & $(<0.0001)$ & $* * *$ & $(<0.0001)$ & $* \star \star$ & $(0.5722)$ & & $(0.0227)^{* *}$ & \\
\hline \multirow[t]{4}{*}{ Latin America } & & 131 & 3.02 & & 3.18 & & 2.48 & & 2.22 & & 2.13 & & 2.72 & & $-43.38 \%^{* * *}$ & $(0.0081)$ & $15.08 \%$ *** & $(0.0033)$ \\
\hline & Negative & 76 & 3.23 & & 3.39 & & 2.38 & & 2.00 & & 1.84 & & 2.16 & & $-42.84 \% \%^{* \star *}$ & $(0.0052)$ & $11.82 \%$ ** & $(0.0429)$ \\
\hline & Positive & 55 & 2.74 & & 2.87 & & 2.65 & & 3.06 & & 2.62 & & 3.38 & & $-45.95 \%$ & $(0.4383)$ & $23.88 \%$ ** & $(0.0266)$ \\
\hline & & & $(0.6254)$ & & $(0.2217)$ & & $(0.1312)$ & & $(0.0041)$ & $* * *$ & $(0.0292)$ & $* *$ & $(0.0007)$ & $* \star *$ & $(0.3364)$ & & $(0.6297)$ & \\
\hline
\end{tabular}

${ }^{*}{ }^{* \star}$ and ${ }^{* \star *}$ indicate that the coefficient is significantly different from zero at the $0.1,0.05$ and 0.01 levels or better, respectively.

Table IX. Interest Coverage.

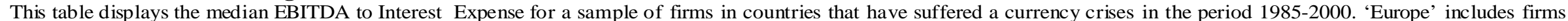

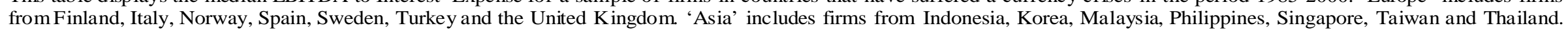

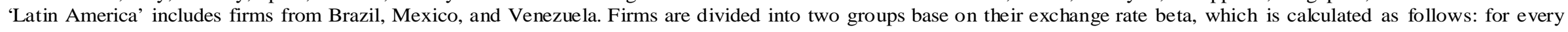

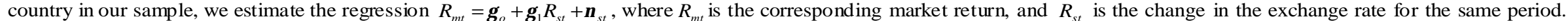

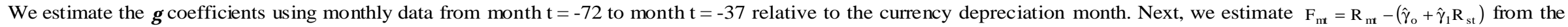

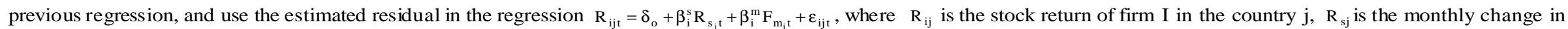

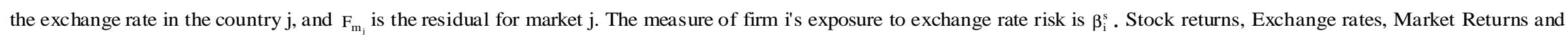

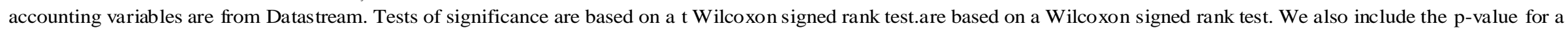

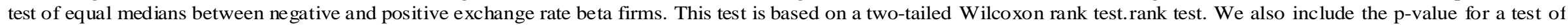
equal medians between negative and positive exchange rate beta firms. This test is based on a two-tailed Wilcoxon rank test. 


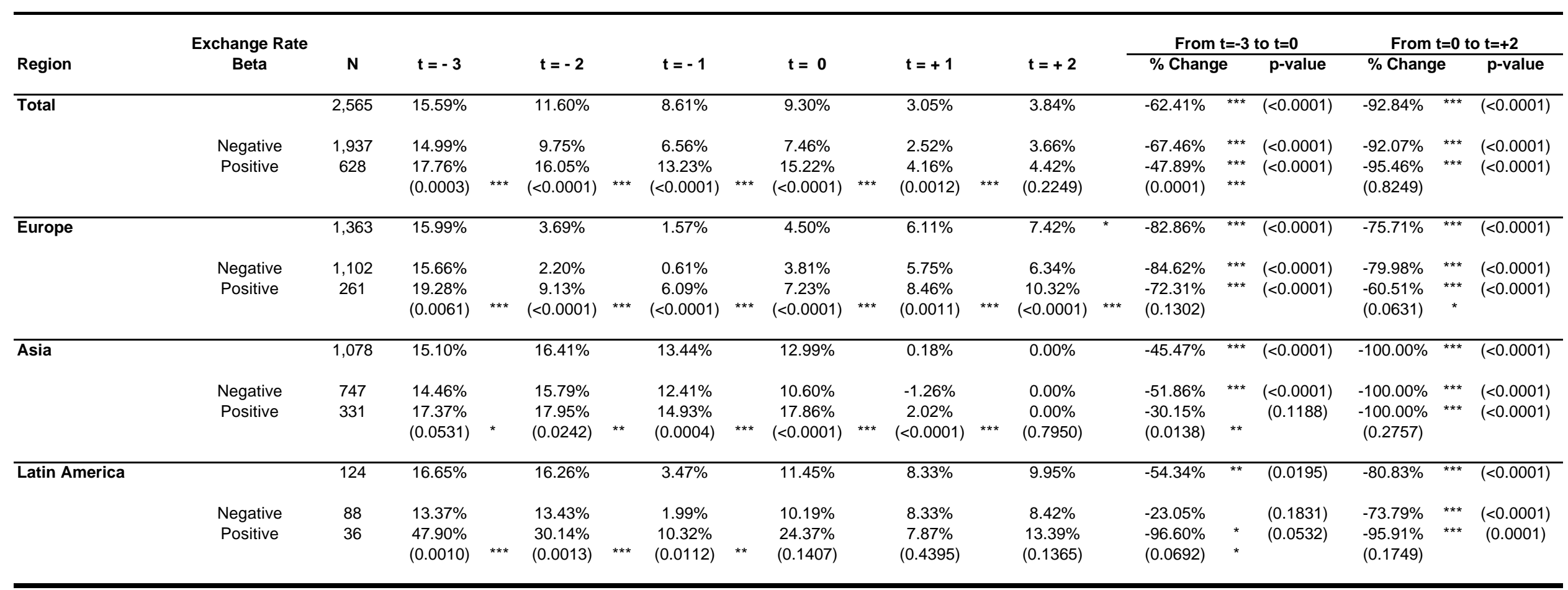

\section{${ }^{\star},{ }^{\star \star}$ and ${ }^{\star \star \star}$ indicate that the coefficient is significantly different from zero at the $0.1,0.05$ and 0.01 levels or better, respectively.}

\section{Table X. Changes in Net Investment.}

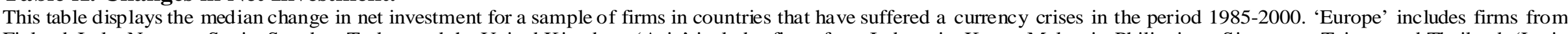

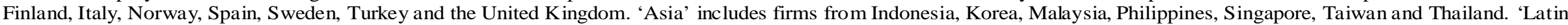

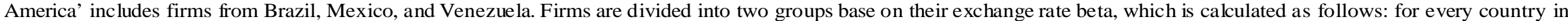

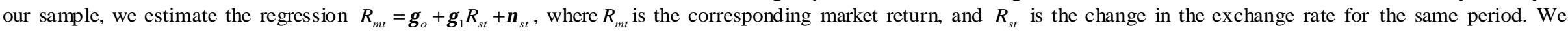

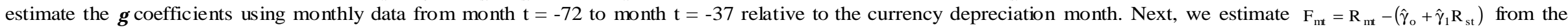

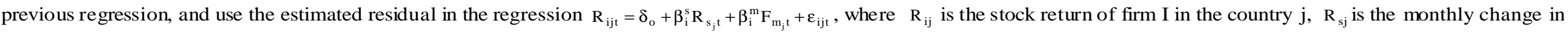

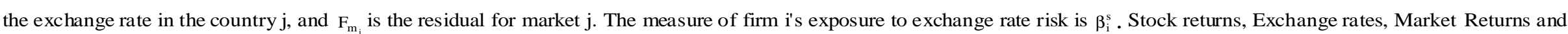

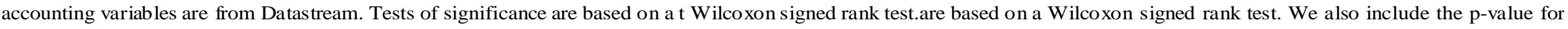

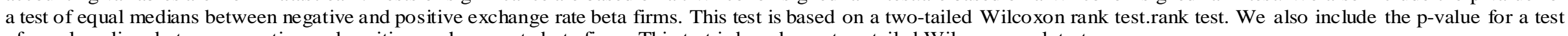
of equal medians between negative and positive exchange rate beta firms. This test is based on a two-tailed Wilcoxon rank test. 
Panel I: Capital Structure and Corporate Governance Variables

\begin{tabular}{|c|c|c|c|c|c|c|c|c|c|c|c|c|}
\hline \multirow[b]{3}{*}{ Variable } & \multirow{2}{*}{\multicolumn{2}{|c|}{ Model I }} & & & & & & & & & & \\
\hline & & & \multicolumn{2}{|c|}{ Model II } & \multicolumn{2}{|c|}{ Model III } & \multicolumn{2}{|c|}{ Model IV } & \multicolumn{2}{|c|}{ Model V } & \multicolumn{2}{|c|}{ Model VI } \\
\hline & Estimate & $\mathrm{p}$-value & Estimate & $p$-value & Estimate & $p$-value & Estimate & $p$-value & Estimate & $\mathrm{p}$-value & Estimate & $p$-value \\
\hline Intercept & -0.2320 ** & $(0.0191)$ & $-0.0665 * * *$ & $(0.0014)$ & -0.4672 & $(0.1057)$ & & & & & $4.3429 * * *$ & * $(0.0013)$ \\
\hline Average Debt to Equity Ratio & 0.0092 & $(0.1429)$ & & & 0.0868 * & $(0.0786)$ & $-0.0132 *$ & $(0.0989)$ & & & & \\
\hline Debt to Equity Ratio for $\beta_{x}^{-}$ & & & -0.1939 * & $(0.0814)$ & & & & & -2.8769 * & $(0.0675)$ & $-6.0641 * * \star *$ & * $(0.0016)$ \\
\hline Debt to Equity Ratio for $\beta_{x}^{+}$ & & & -0.9166 & $(0.1924)$ & & & & & -5.5980 & $(0.1134)$ & $-1.7423 * *$ & $(0.0127)$ \\
\hline Corruption Index (Lower Score, High Corruption) & & & & & -0.0905 ** & $(0.0363)$ & & & & & $-1.8915 * * *$ & $*(0.0070)$ \\
\hline Efficiency of Judicial System & & & & & $0.0276^{* * *}$ & $=(0.0036)$ & & & & & -0.2060 & $(0.1457)$ \\
\hline GDP & & & & & $-0.0003^{* * *}$ & $(<0.0001)$ & & & & & $0.0031^{* *}$ & $(0.0282)$ \\
\hline Rule of Law & & & & & $0.0613^{* * *}$ & $(0.0078)$ & & & & & 0.9184 ** & $(0.0160)$ \\
\hline Legal Mother is Germany & & & & & & & $-0.2841 * *$ & $(0.0407)$ & 1.4069 & $(0.1508)$ & & \\
\hline Legal Mother is United Kingdom & & & & & & & $-0.0938 * *$ & $(0.0106)$ & 1.0146 & $(0.1168)$ & & \\
\hline Legal Mother is Scandinavia & & & & & & & -0.1684 ** & $(0.0130)$ & -1.9114 & $(0.1454)$ & & \\
\hline Number of Observations & 17 & & 17 & & 17 & & 17 & & 17 & & 17 & \\
\hline Adjusted R-squared & -0.0660 & & 0.1148 & & -0.1642 & & 0.4998 & & 0.5077 & & 0.6615 & \\
\hline
\end{tabular}

${ }^{* *}$ and ${ }^{* \star}$ indicate that the coefficient is significantly different from zero at the $0.1,0.05$ and 0.01 levels or better, respectively.

Panel II: Capital Structure, Corporate Governance Variables, and Macro Variables

\begin{tabular}{|c|c|c|c|c|c|c|c|c|c|c|c|c|}
\hline \multirow[b]{3}{*}{ Variable } & \\
\hline & \multicolumn{2}{|c|}{ Model VII } & \multicolumn{2}{|c|}{ Model VIII } & \multicolumn{2}{|c|}{ Model IX } & \multicolumn{2}{|c|}{ Model X } & \multicolumn{2}{|c|}{ Model XI } & \multicolumn{2}{|c|}{ Model XII } \\
\hline & Estimate & $\mathrm{p}$-value & Estimate & $\mathrm{p}$-value & Estimate & p-value & Estimate & $p$-value & Estimate & $\mathrm{p}$-value & Estimate & $p$-value \\
\hline $\begin{array}{l}\text { Intercept } \\
\text { Average Debt to Equity Ratio }\end{array}$ & -0.2582 ** & $(0.0106)$ & -0.1544 ** & $(0.0138)$ & $-0.1459 * \star \star *$ & $(0.0091)$ & $\begin{array}{l}-0.3464 \\
-0.4097\end{array}$ & $(0.1393)$ & -0.5731 * & $(0.0533)$ & & \\
\hline Debt to Equity Ratio for $\beta^{-}$ & & & & & -0.4822 & $(0.1745)$ & & & -0.0939 & (0.7132) & -0.3243 * & $(0.0957)$ \\
\hline Debt to Equity Ratio for $p_{p_{x}}$ & & & & & -0.2952 & $(0.2424)$ & & & -0.0332 * & $(0.0549)$ & 0.3362 & $(0.2556)$ \\
\hline Corruption Index (Lower Score, High Corruption) & & & & & & & $-0.0495 * *$ & $(0.0431)$ & $0.0151^{* * *}$ & $(0.0047)$ & & \\
\hline Efficiency of Judicial System & & & & & & & $0.0039 * * *$ & $(0.0048)$ & $0.0003 * \star \star x$ & $(<0.0001)$ & & \\
\hline & 1.4009 & $(0.5993)$ & $0.0002^{* * \star}$ & $(<0.0001)$ & $0.0003^{* \star *}$ & $(0.0000)$ & 0.0002 *** & $(<0.0001)$ & 0.0390 ** & $(0.0138)$ & & \\
\hline Rule of Law & & & & & & & $0.0549 * * *$ & $(0.0093)$ & & & & \\
\hline Legal Mother is Germany & & & & & & & & & & & -0.2400 ** & $(0.0243)$ \\
\hline Legal Mother is Spain and France & & & & & & & & & & & $-0.2961 * *$ & $(0.0160)$ \\
\hline $\begin{array}{l}\text { Legal Mother is United Kingdom } \\
\text { Lem }\end{array}$ & & & & & & & & & & & -0.0952 *** & $=(0.0080)$ \\
\hline Legal Mother is Scandinavia & & & & & & & & & & & -0.1324 ** & $(0.0100)$ \\
\hline Current Account Deficit One Year Prior to Crisis & $0.34078 * \star *$ & $(<0.0001)$ & 0.7805 & $(0.2774)$ & 0.7319 & $(0.2532)$ & 0.0899 & $(0.6886)$ & -0.0484 & $(0.5392)$ & 0.4323 & $(0.1982)$ \\
\hline Budget Deficit One Year Prior to Crisis & $0.02166^{* \star *}$ & $(<0.0001)$ & $0.0126^{* * *}$ & $(<0.0001)$ & $0.0145 * * *$ & $(<0.0001)$ & $0.0127^{* \star *}$ & $(<0.0001)$ & $0.0151^{\star \star \star *}$ & $(<0.0001)$ & $0.0089 * * *$ & $=(<0.0001)$ \\
\hline Number of Observations & $\begin{array}{c}17 \\
03851\end{array}$ & & 17 & & 17 & & 17 & & 17 & & 17 & \\
\hline
\end{tabular}

Table XI. Currency Depreciation and Firm Leverage.

This table reports the results of the regression of the amount of depreciation from months $t=-2$ to $t=+2$ on the variables listed under the variables column for countries that have suffered a currency crises in the period 1985-2000. Firms are divided into two groups base on their exchange rate beta, which is calculated as follows: for every country in our sample, we estimate the regression $R_{m t}=\gamma_{o}+\gamma_{1} R_{s t}+v_{s t}$, where $R_{m t}$ is the corresponding market return, and $R_{s t}$ is the change in the exchange rate for the same period. We estimate the $\gamma$ coefficients using monthly data from month $t=-72$ to month $t=-37$ relative to the currency depreciation month. Next, we estimate $F_{\mathrm{mt}}=\mathrm{R}_{\mathrm{mt}}-\left(\hat{\gamma}_{\mathrm{o}}+\hat{\gamma}_{1} \mathrm{R}_{\mathrm{st}}\right)$ from the previous regression, and use the estimated residual in the regression $R_{i j t}=\delta_{o}+\beta_{i}^{s} R_{s i t}+\beta_{i}^{m} F_{m_{i} t}+\varepsilon_{i j t}$, where $R_{i j}$ is the stock return of firm I in the country $j$, Ris the monthly change in the exchange rate in the country $j$, and $F_{m_{j}}$ is the residual for market $j$. The measure of firm i's exposure to exchange rate risk is $\beta_{i}^{s}$. Exchange rates and accounting variables are from Datastream. The variables "Rule of Law", "Corruption", "Risk of Expropriation", and "Efficiency of the Judicial System" are from La Porta et al. (1998). GDP data is obtained from Economist Intelligence Unit database. P-values, T-Statistics and Standard Errors have been corrected for heteroskedasticity following the approach in White (1980). 


\begin{tabular}{|c|c|c|c|c|c|c|c|c|c|c|c|c|}
\hline \multirow[b]{3}{*}{ Variable } & \multicolumn{2}{|r|}{ Model I } & \multicolumn{2}{|r|}{ Model II } & \multicolumn{3}{|c|}{ Model III } & \multirow{3}{*}{$\frac{\text { Model IV }}{\text { p-value }}$} & \multicolumn{2}{|r|}{ Model V } & \multicolumn{2}{|r|}{ Model VI } \\
\hline & & & & & & & in America & & Asia & & Europe & \\
\hline & Estimate & $\mathrm{p}$-value & Estimate & $\mathrm{p}$-value & Estimate & $\mathrm{p}$-value & Estimate & & Estimate & $p$-value & Estimate & $p$-value \\
\hline Intercept & & & & & & & $0.1646^{* \star *}$ & $(0.0028)$ & $0.5092 * \star \star *$ & $(0.0000)$ & $0.1706^{\star \star \star *}$ & $(<0.0001)$ \\
\hline Exchange Rate Beta & $-1.46 \mathrm{E}-07^{\star * \star}$ & $(0.0001)$ & $-1.34 \mathrm{E}-07^{\star * \star}$ & $(0.0008)$ & $-1.12 \mathrm{E}-07^{* \star *}$ & $(<0.001)$ & $-3.95 \mathrm{E}-08$ & $(0.2321)$ & $-1.90 \mathrm{E}-02 * \star \star$ & $(0.0001)$ & $-3.16 \mathrm{E}-02^{* * *}$ & $(0.0022)$ \\
\hline Firm Size & $0.0232 * * *$ & $(<0.0001)$ & $0.0230 * * *$ & $(<0.0001)$ & $0.0238^{* * *}$ & $(<0.001)$ & -0.0542 ** & $(0.0242)$ & $0.0352 * * *$ & $(0.0003)$ & -0.0021 & $(0.3751)$ \\
\hline EBIT / Total Assets & $-2.60 \mathrm{E}-06$ ** & $(0.0191)$ & $-2.57 \mathrm{E}-06$ ** & $(0.0212)$ & $-2.48 \mathrm{E}-06$ & $(0.6520)$ & 3.90E-03 & $(0.4226)$ & $(<0.0001)^{* * *}$ & $(0.0001)$ & $-1.17 \mathrm{E}-03$ * & $(0.0606)$ \\
\hline Market to Book Ratio & $0.0025^{* * *}$ & $(0.0091)$ & 0.0023 ** & $(0.0134)$ & 0.0022 * & $(0.0765)$ & 0.0000 & $(0.4759)$ & -0.0030 & $(0.3132)$ & $0.1601^{* * *}$ & $(<0.0001)$ \\
\hline Corruption Index (Lower Score, High Corruption) & -0.2011 *** & $(<0.0001)$ & $-0.1734^{\star \star *}$ & $(0.0056)$ & & & & & & & & \\
\hline Efficiency of Judicial System & -0.0123 & $(0.1050)$ & -0.0100 & $(0.2243)$ & & & & & & & & \\
\hline Enforceability of Contracts & 0.0829 * & $(0.0587)$ & -0.0411 & $(0.3758)$ & & & & & & & & \\
\hline Log GDP per Capita & $0.2890 * \star *$ & $(<0.0001)$ & $0.2573^{* * *}$ & $(<0.0001)$ & & & & & & & & \\
\hline Risk of Expropriation (Lower Score, High Risk) & $-0.7698 * * *$ & $(<0.0001)$ & $-0.5784^{* \star *}$ & $(0.0004)$ & & & & & & & & \\
\hline Government Repudiation of Contracts (Lower Score, High Risk) & -0.0255 & $(0.1426)$ & 0.0251 & $(0.2811)$ & & & & & & & & \\
\hline Rule of Law & $0.1292^{\star * \star}$ & $(<0.0001)$ & 0.0749 ** & $(0.0321)$ & & & & & & & & \\
\hline Dummy for Asian Countries & 0.0378 & $(0.3313)$ & 0.0511 & $(0.3626)$ & & & & & & & & \\
\hline Dummy for European Countries & $-0.3145^{* * *}$ & $(0.0009)$ & -0.2046 & $(0.1961)$ & & & & & & & & \\
\hline Dummy for Latin American Countries & $-0.6093 * \star \star$ & $(<0.0001)$ & -0.4920 ** & $(0.0251)$ & & & & & & & & \\
\hline Legal Mother is Germany & & & -0.1817 ** & $(0.0480)$ & & & & & & & & \\
\hline Legal Mother is France and Spain & & & -0.1466 & $(0.1495)$ & & & & & & & & \\
\hline Legal Mother is United Kingdom & & & -0.1023 ** & $(0.0353)$ & & & & & & & & \\
\hline Number of Observations & 1,601 & & 1,601 & & 1,601 & & 53 & & 856 & & 689 & \\
\hline R-square & 0.7805 & & 0.7805 & & 0.9656 & & 0.0518 & & 0.0624 & & 0.3470 & \\
\hline
\end{tabular}

${ }^{*},{ }^{* \star}$ and ${ }^{* \star *}$ indicate that the coefficient is significantly different from zero at the $0.1,0.05$ and 0.01 levels or better, respectively.

\section{Table XII. Firm Leverage and Currency Exposure.}

This table reports the results of the regression of a firm's debt-to-value ratio on the variables listed under the variables column for countries that have suffered a currency crises in the period 1985-2000. Europe' includes firms from Finland, Norway, Spain, Sweden, Turkey and the United Kingdom. 'Asia' includes firms from Indonesia, Korea, Malaysia, Philippines, Singapore, Taiwan and Thailand. 'Latin America' includes firms from Brazil, Mexico, and Venezuela. Firms are divided into two groups base on their exchange rate beta, which is calculated as follows: for every country in our sample, we estimate the regression $R_{m t}=\gamma_{o}+\gamma_{1} R_{s t}+v_{s t}$, wher $R_{m t}$ is the corresponding market return, and $R_{s}$ is the change in the exchange rate for the same period. We estimate the $\gamma$ coefficients using monthly data from month $t=-72$ to month $t=-37$ relative to the currency depreciation month. Next, we estimate $F_{n t}=R_{n t}-\left(\hat{\gamma}_{0}+\hat{\gamma}_{1} R_{s t}\right)$ from the previous regression, and use the estimated residual in the regression $R_{i j t}=\delta_{o}+\beta_{i}^{s} R_{s, t}+\beta_{i}^{m} F_{m, t}+\varepsilon_{i j t}$, where $R_{i j}$ is the stock return of firm I in the country j, Ris the monthly change in the exchange rate in the country $\mathrm{j}$, and $\mathrm{F}_{\mathrm{m}_{\mathrm{i}}}$ is the residual for market $\mathrm{j}$. The measure of firm i's exposure to exchange rate risk iss $\beta_{i}^{\mathrm{s}}$. Exchange rates and accounting variables are from Datastream. The variables "Log GDP per capita", "Rule of Law", "Corruption", and "Efficiency of the Judicial System" are from La Porta et al. (1998). P-values have been corrected for heteroskedasticity following the approach in White (1980). All R-squares are adjusted. Model III is estimated with country-fixed effects. The coefficient for the exchange rate beta variable has been multiplied by $10^{6}$. 


\section{Latin America}

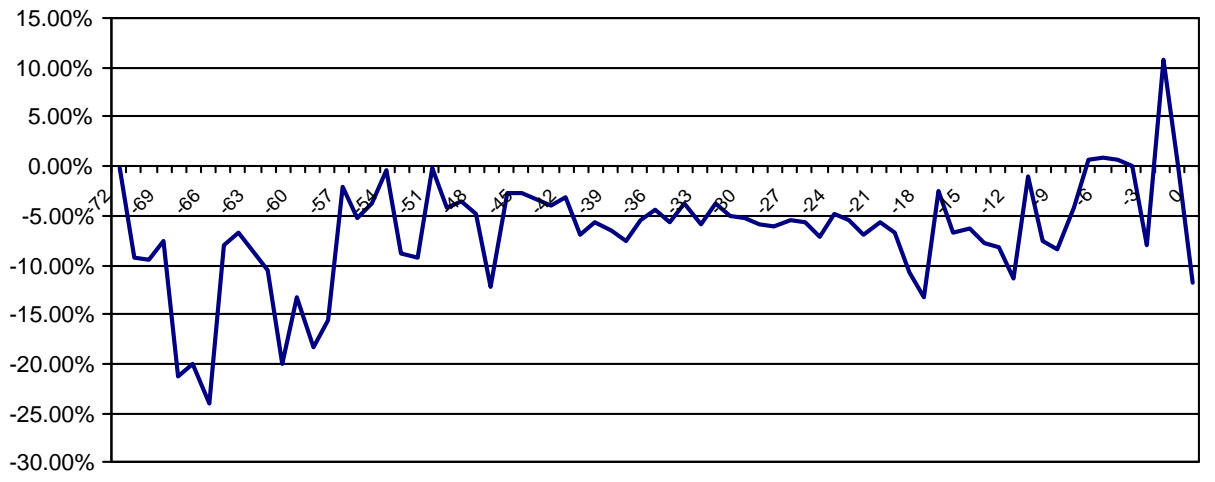

\section{Europe}

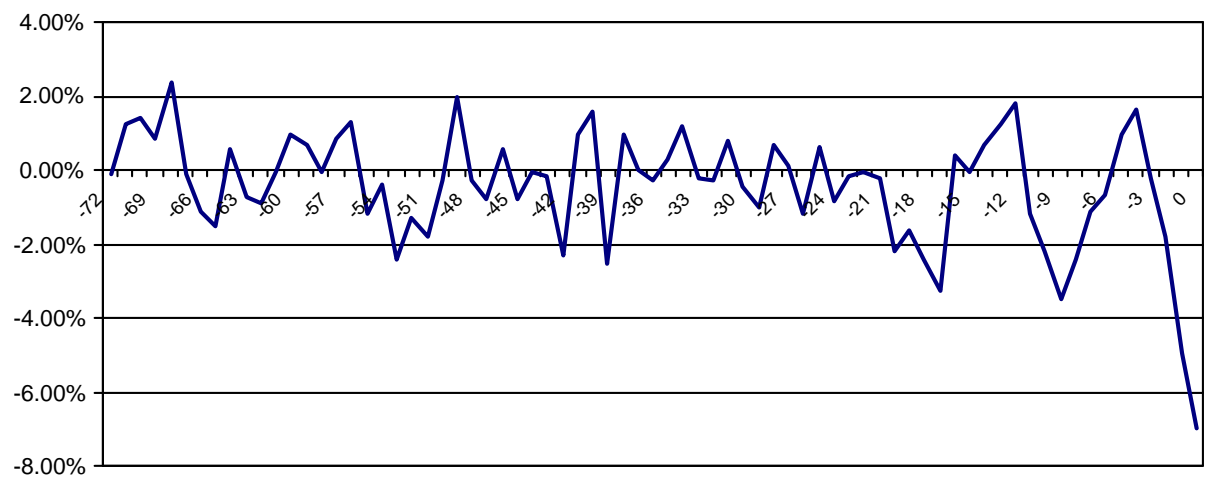

Asia

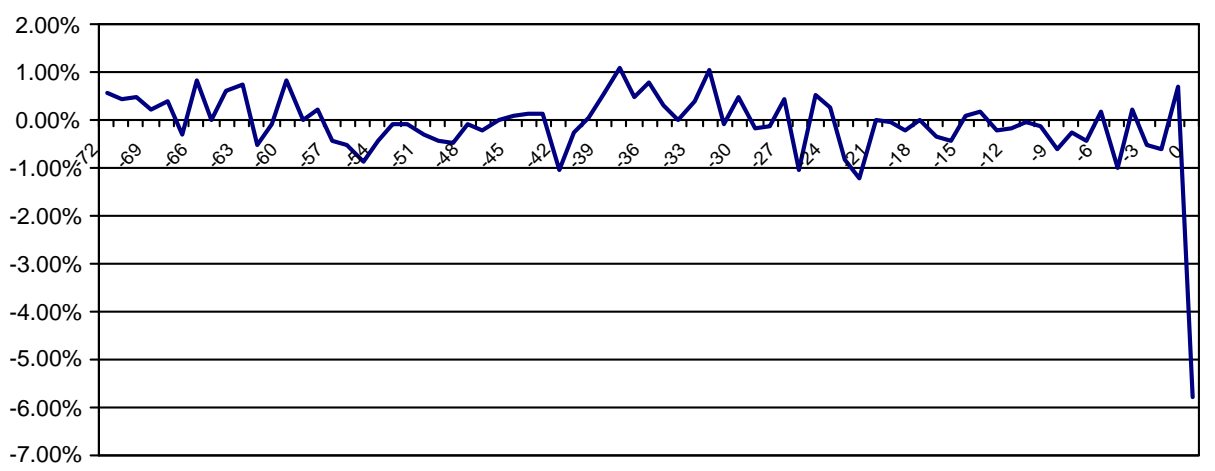

Figure 1

Exchange Rate Changes before Currency Crises

The graph shows the average appreciation / depreciation of the nominal exchange rate US dollar / domestic currency in the 72 months preceding the currency crises in Latin America (Brazil, Mexico, and Venezuela), Europe (Finland, Italy, Norway, Spain, Sweden, Turkey, and the United Kingdom), Asia (Indonesia, Malaysia, Philippines, Singapore, South Korea, Taiwan, and Thailand), considered in the paper. 


\section{DAVIDSON INSTITUTE WORKING PAPER SERIES - Most Recent Papers}

The entire Working Paper Series is available at: www.wdi.bus.umich.edu

CURRENT AS OF 9/13/01

\begin{tabular}{|c|c|c|}
\hline Publication & Authors & Date \\
\hline $\begin{array}{l}\text { No. } 386 \text { Corporate Financial Policies and Performance Prior to Currency } \\
\text { Crises }\end{array}$ & $\begin{array}{l}\text { Arturo Bris, Yrjö Koskinen, and } \\
\text { Vicente Pons }\end{array}$ & June 2001 \\
\hline No. 385 Ownership and Productive Efficiency: Evidence from Estonia & Derek C. Jones and Niels Mygind & Aug. 2001 \\
\hline No. 384 Institutional Determinants of Labor Reallocation in Transition & Tito Boeri and Katherine Terrell & June 2001 \\
\hline $\begin{array}{l}\text { No. } 383 \text { Deindustrialisation and Structural Change During the Post- } \\
\text { Communist Transition }\end{array}$ & $\begin{array}{l}\text { Tomasz Mickiewicz and Anna } \\
\text { Zalewska }\end{array}$ & June 2001 \\
\hline No. 382 Markets and Growth & Štěpán Jurajda and Janet Mitchell & July 2001 \\
\hline $\begin{array}{l}\text { No. } 381 \text { Labor Market Discrimination During Post-Communist } \\
\text { Transition: A Monopsony Approach to the Status of Latvia's Russian } \\
\text { Minority }\end{array}$ & Robert S. Chase & Sept. 2000 \\
\hline No. 380 Dollarization of Liabilities in Non-tradable Goods Sector & Frédéric Chabellard & June 2001 \\
\hline $\begin{array}{l}\text { No. } 379 \text { Lessons from the Russian Meltdown: The Economics of Soft } \\
\text { Legal Constraints }\end{array}$ & Enrico Perotti & Mar. 2001 \\
\hline No. 378 Effective Tax Rates in Transition & Vlad Ivanenko & May 2001 \\
\hline $\begin{array}{l}\text { No. } 377 \text { Some Explanations for Changes in the Distribution of } \\
\text { Household Income in Slovakia: } 1988 \text { and } 1996\end{array}$ & $\begin{array}{l}\text { Thesia Garner and Katherine } \\
\text { Terrell }\end{array}$ & May 2001 \\
\hline $\begin{array}{l}\text { No. } 376 \text { Competition and Enterprise Performance in Transition } \\
\text { Economies: Evidence from a Cross-country Survey }\end{array}$ & $\begin{array}{l}\text { Wendy Carlin, Steven Fries, } \\
\text { Mark Schaffer and Paul Seabright }\end{array}$ & 2001 \\
\hline $\begin{array}{l}\text { No. } 375 \text { Why More is Actually Less: New Interpretations of China's } \\
\text { Labor-Intensive FDI }\end{array}$ & Yasheng Huang & May 2001 \\
\hline No. 374 Economic Fragmentation and FDI in China & uang & May 2001 \\
\hline $\begin{array}{l}\text { No. } 373 \text { Earnings Disparities in the Czech Republic: Evidence of the } \\
\text { Past Decade and Cross-National Comparison }\end{array}$ & Jiri Vecernik & May 2001 \\
\hline $\begin{array}{l}\text { No. } 372 \text { Economic Reform, Democracy and Growth During Post- } \\
\text { Communist Transition }\end{array}$ & Jan & Mar. 2001 \\
\hline $\begin{array}{l}\text { No. } 371 \text { Do Multinational Enterprises Substitute Parent Jobs for Foreign } \\
\text { Ones? Evidence from Firm Level Panel Data }\end{array}$ & Jozef Konings and $\mathrm{A}$ & Apr. 2001 \\
\hline $\begin{array}{l}\text { No. } 370 \text { From Needs to the Market: Changing Inequality of Household } \\
\text { Income in the Czech Transition }\end{array}$ & Jiri Vecernik & Apr. 2001 \\
\hline $\begin{array}{l}\text { No. } 369 \text { Competition and Corporate Governance: Substitutes or } \\
\text { Complements? Evidence from the Warsaw Stock Exchange }\end{array}$ & $\begin{array}{l}\text { Irena Grosfeld and Thierry } \\
\text { Tressel }\end{array}$ & Mar. 2001 \\
\hline $\begin{array}{l}\text { No. } 368 \text { Multinational Corporations as Catalyst for Industrial } \\
\text { Development: The Case of Poland }\end{array}$ & $\begin{array}{l}\text { Carlo Altomonte and Laura } \\
\text { Resmini }\end{array}$ & Feb. 2001 \\
\hline No. 367 A Multi-Task Theory of the State Enterprise Reform & $\begin{array}{l}\text { Chong-En Bai, David D. Li, } \\
\text { Zhigang Tao, and Yijiang Wang }\end{array}$ & Mar. 2001 \\
\hline No. 366a Confidence Building in Emerging Stock Markets & Enrico C. Perotti and Luc Laeven & June 2001 \\
\hline No. 366 Confidence Building in Emerging Stock Markets & $\begin{array}{l}\text { Enrico C. Perotti, Luc Laeven, } \\
\text { and Pieter van Oijen }\end{array}$ & Dec. 2000 \\
\hline $\begin{array}{l}\text { No. } 365 \text { Incentive Contracting versus Ownership Reforms: Evidence } \\
\text { from China's Township and Village Enterprises }\end{array}$ & $\begin{array}{l}\text { Chun Chang, Brian McCall, and } \\
\text { Yijang Wang }\end{array}$ & Nov. 2000 \\
\hline $\begin{array}{l}\text { No. } 364 \text { Individual Pay and Outside Options: Evidence from the Polish } \\
\text { Labour Force Survey }\end{array}$ & $\begin{array}{l}\text { Fiona Duffy and Patrick Paul } \\
\text { Walsh }\end{array}$ & Mar. 2001 \\
\hline $\begin{array}{l}\text { No. } 363 \text { Investment, Credit Rationing and the Soft Budget Constraint: } \\
\text { Evidence from Czech Panel Data (revised Davidson Institute Working } \\
\text { Paper No. 60a) }\end{array}$ & Lubomír Lízal and Jan Svejnar & Feb. 2001 \\
\hline
\end{tabular}

